\title{
Bacterial and Fungal Contributions to Carbon Sequestration in Agroecosystems
}

\author{
J. Six,* S. D. Frey, R. K. Thiet, and K. M. Batten
}

\begin{abstract}
This paper reviews the current knowledge of microbial processes affecting $\mathrm{C}$ sequestration in agroecosystems. The microbial contribution to soil $\mathrm{C}$ storage is directly related to microbial community dynamics and the balance between formation and degradation of microbial byproducts. Soil microbes also indirectly influence $\mathbf{C}$ cycling by improving soil aggregation, which physically protects soil organic matter (SOM). Consequently, the microbial contribution to $\mathrm{C}$ sequestration is governed by the interactions between the amount of microbial biomass, microbial community structure, microbial byproducts, and soil properties such as texture, clay mineralogy, pore-size distribution, and aggregate dynamics. The capacity of a soil to protect microbial biomass and microbially derived organic matter (MOM) is directly and/or indirectly (i.e., through physical protection by aggregates) related to the reactive properties of clays. However, the stabilization of MOM in the soil is also related to the efficiency with which microorganisms utilize substrate $C$ and the chemical nature of the byproducts they produce. Crop rotations, reduced or no-tillage practices, organic farming, and cover crops increase total microbial biomass and shift the community structure toward a more fungal-dominated community, thereby enhancing the accumulation of MOM. A quantitative and qualitative improvement of SOM is generally observed in agroecosystems favoring a fungal-dominated community, but the mechanisms leading to this improvement are not completely understood. Gaps within our knowledge on MOM-C dynamics and how they are related to soil properties and agricultural practices are identified.
\end{abstract}

$\mathrm{G}$ REATER THAN two-thirds of the organic $\mathrm{C}$ stored in terrestrial ecosystems is contained in SOM, with the net flux of $\mathrm{C}$ from soils to the atmosphere being on the order of $60 \mathrm{Pg} \mathrm{C} \mathrm{yr}^{-1}$ (Schlesinger, 1997). The historical loss of soil $\mathrm{C}$ due to intensive cultivation is estimated to be about $55 \mathrm{Pg} \mathrm{C}$ or $25 \%$ of the original C present in virgin, uncultivated soils, and has contributed significantly to $\mathrm{CO}_{2}$ release to the atmosphere on a global scale (Cole et al., 1997). The potential for agricultural soils to regain some of this lost $\mathrm{C}$ is being evaluated as a means to improve soil fertility, reduce erosion, and mitigate $\mathrm{CO}_{2}$ emissions.

Increasing the potential for agricultural soils to sequester $\mathrm{C}$ requires a thorough understanding of the underlying processes and mechanisms controlling soil $\mathrm{C}$ levels, for which a great deal of knowledge already exists. Previous reviews have examined the relationships between microbial communities and SOM decomposition (Scow, 1997), management controls on soil C (Paustian et al., 1997), and the macromolecular compo-

J. Six and K.M. Batten, Dep. of Plant Sciences, Univ. of California, Davis, CA 95616; S.D. Frey and R.K. Thiet, Dep. of Natural Resources, Univ. of New Hampshire, Durham, NH 03824. Received 1 Nov. 2004.*Corresponding author(jwsix@ucdavis.edu).

Published in Soil Sci. Soc. Am. J. 70:555-569 (2006).

Soil Biology \& Biochemistry

doi:10.2136/sssaj2004.0347

(c) Soil Science Society of America

677 S. Segoe Rd., Madison, WI 53711 USA sition of SOM (Kogel-Knabner, 2002). Here, we focus specifically on how soil bacteria and fungi may differentially influence the formation and stabilization of different SOM components in agricultural soils via differences in metabolism, the recalcitrance of microbial products, and interactions with soil physical properties (i.e., texture, mineralogy, and structure).

Soil $\mathrm{Clevels}$ are fundamentally determined by the balance between organic matter inputs, primarily as plant residues, roots, and root exudates, and organic matter losses due to decomposition, erosion, and leaching. Bacteria and fungi generally comprise $>90 \%$ of the total soil microbial biomass, and they are responsible for the majority of SOM decomposition. Since soil microbial communities are key regulators of SOM dynamics and nutrient availability, shifts in microbial community composition and function (e.g., substrate utilization) in response to different agricultural management practices may play an important role in determining rates of $\mathrm{C}$ loss from the soil. The ratio of fungal:bacterial biomass has been shown to be particularly sensitive to soil disturbance, with lower ratios associated with increased intensity of cultivation (Bailey et al., 2002; Beare et al., 1992; Frey et al., 1999), increased grazing pressure (Bardgett et al., 1996, 1998), and increased N fertilization inputs (Bardgett and McAlister, 1999; Bardgett et al., 1996, 1999; Frey et al., 2004). In addition, fungal: bacterial biomass ratios were found to increase with successional age in a semiarid grassland community (Klein et al., 1996) and along an Alaskan forest chronosequence (Ohtonen et al., 1999). Substrate quality also alters fungal:bacterial ratios, with low quality substrates (high $\mathrm{C} / \mathrm{N}$ ) favoring fungi and high quality (low $\mathrm{C} / \mathrm{N}$ ) substrates favoring bacteria (Bossuyt et al., 2001).

Organic $\mathrm{C}$ taken up by the microbial biomass is partitioned between microbial cell biomass production, metabolite excretion, and respiration (Fig. 1). The degree to which MOM accumulates in soil depends on a balance between production and decomposition of microbial products, that is: (1) the microbial growth efficiency (MGE), the efficiency with which substrates are incorporated into bacterial and fungal biomass and byproducts, (2) the degree of protection of microbial biomass in the soil structure, and (3) the rate at which bacterial and fungal byproducts are decomposed by other microorganisms. The proportion of substrate $\mathrm{C}$ retained as biomass versus respired as $\mathrm{CO}_{2}$ depends on MGE and the degree of protection of microbial biomass; the lower the MGE or the less protected the biomass, the more MOM-C is lost as $\mathrm{CO}_{2}$ (Fig. 1, Step I). Substrate C can

Abbreviations: CT, conventional tillage; LF, light fraction; MAP, mean annual precipitation; MAT, mean annual temperature; MGE, microbial growth efficiency; MOM, microbially derived organic matter; MT, minimum tillage; NT, no-tillage; POM, plant-derived organic matter; SOM, soil organic matter. 


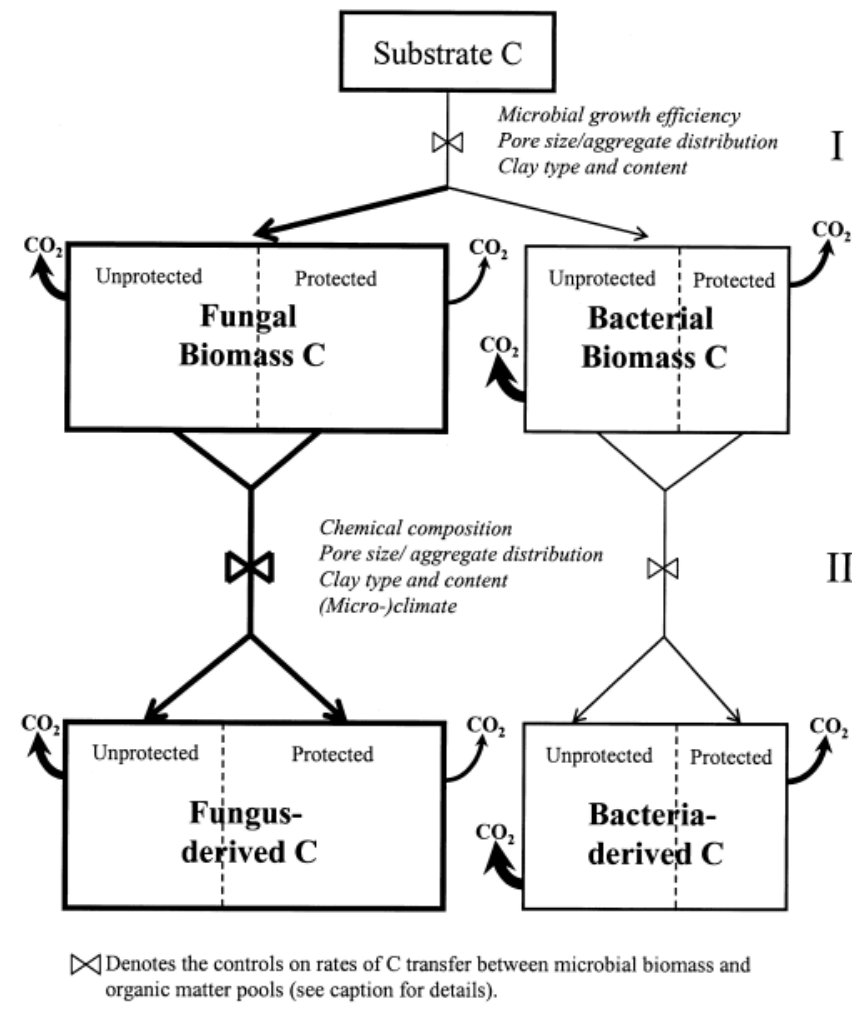

Fig. 1. This conceptual diagram depicts our current understanding of the microbial contribution to $\mathrm{C}$ sequestration in agroecosystems. Microbial $\mathrm{C}$ pool sizes are indicated by the relative size of the boxes, and the relative rate of $\mathrm{C}$ transfer from one pool to another (including $\mathrm{CO}_{2}$ evolution) is represented by arrow thickness. In Step I, substrate $\mathrm{C}$ is partitioned between bacterial and fungal biomass. The amount of $\mathrm{C}$ incorporated into biomass and metabolite production versus that lost as $\mathrm{CO}_{2}$ is dependent on the microbial growth efficiency of the microbial community. The amount of bacterial versus fungal biomass is also determined by the relative degree of protection conferred by the soil matrix (characterized by pore and aggregate size distribution and by clay type and content). In Step II, the rate of transfer of microbial biomass $\mathrm{C}$ to microbially derived organic matter is influenced by the chemical recalcitrance of microbial products, the sensitivity of decomposition to (micro)climatic factors, and differential interactions between bacterial and fungal products and the soil matrix. We suggest that a fungaldominated microbial community improves the physical environment for $\mathbf{C}$ stabilization and produces more protected and stable $\mathbf{C}$.

also be converted into stable, nonmicrobially processed organic matter, but this is not the focus of our review. After incorporation into microbial biomass, $\mathrm{C}$ is converted into stable MOM or decomposed and respired as $\mathrm{CO}_{2}$. At this step, the proportion of $\mathrm{C}$ retained in the soil depends on the chemical recalcitrance and degree of protection of the organic matter (Fig. 1, Step II). Soil $\mathrm{C}$ retention is additionally governed by microclimate, clay content and type, pore-size distribution, and aggregate dynamics.

Our review is organized around two prevailing but rarely tested paradigms that taken together predict that microbial communities with a predominance of fungal biomass and activity will sequester more $\mathrm{C}$ than bacterialdominated communities (Beare, 1997; Bailey et al., 2002; Fig. 1). The first paradigm states that the production of microbial biomass and byproducts will be greater in soils where the microbial community is composed predom- inantly of fungi because fungi have higher MGE than bacteria (Holland and Coleman, 1987). Fungal-dominated communities will, therefore, retain more $\mathrm{C}$ in biomass per unit substrate consumed and release less as $\mathrm{CO}_{2}$ (Fig. 1, Step I). The second paradigm postulates that the degradation of MOM will be slower in soils where fungi predominate because fungal products are more chemically resistant to decay (Martin and Haider, 1979) and are preferentially protected from decomposition through their interactions with clay minerals and soil aggregates (Simpson et al., 2004) (Fig. 1, Step II). If one or both of these ideas hold true, then agricultural management practices that favor fungal dominance would also enhance soil $\mathrm{C}$ sequestration. In this review, we discuss whether existing data support these ideas and suggest areas where further research is needed.

\section{FORMATION OF MICROBIALLY DERIVED SOIL ORGANIC MATTER}

The amount of substrate $\mathrm{C}$ that is incorporated into microbial biomass and eventually transferred into the MOM pool is determined by the size of the microbial biomass and its MGE (Fig. 1, Step I). The amount of microbial biomass is directly related to the $\mathrm{C}$ input level, but is also influenced by other factors including the availability of microbial habitat and consequently, the level of protection provided for the microbial biomass. The latter is the focus of the next section.

\section{Protected versus Unprotected Microbial Biomass}

Microbial biomass can be divided into unprotected and protected pools. Van Veen et al. (1985) split microbial biomass into a protected pool with a death rate of $0.5 \%$ per day and an unprotected pool with a death rate of $70 \%$ per day. A partial differentiation and isolation of protected versus unprotected soil microbial biomass has been achieved by separating the microbial biomass associated with plant residues (i.e., light fraction [LF]) versus that associated with silt and clay particles, the latter being more protected from predation (Chotte et al., 1998; Kandeler et al., 1999b; Ladd et al., 1996; Sorensen et al., 1996). In addition, Swanston et al. (2004) found the microbial biomass associated with the LF to be less metabolically active than that associated with the heavy clay and silt fraction.

Several mechanisms of protection of microbial biomass in soils have been proposed: (i) clays promote microbial growth by maintaining the $\mathrm{pH}$ in the optimal range (Stotzky and Rem, 1966), (ii) clays adsorb metabolites inhibitory to microbial growth (Martin et al., 1976), (iii) clay-microbe interactions protect the organisms against desiccation (Bitton et al., 1976; Bushby and Marshall, 1977), and (iv) microbes reside in small pores in which they are protected against predation by higher trophic groups, notably protozoa (Elliott et al., 1980; Rutherford and Juma, 1992). Since all of these mechanisms are directly or indirectly related to the reactive surface properties of clays, the protective capacity of soils for microbial biomass has often been related to clay 
content (Amato and Ladd, 1992; Franzluebbers et al., 1996; Gregorich et al., 1991; Ladd et al., 1992; Sorensen, 1983a, 1983b; van Veen et al., 1985); however, clay mineralogy may be as important as clay content for microbial biomass protection (Ladd et al., 1992).

The influence of clay type has received much less attention than clay content, and the few studies that have been done have most often been conducted under in vitro conditions with single bacterial species (Bitton et al., 1976; Bushby and Marshall, 1977). Bentonite clay, which includes montmorillonite and other smectite group minerals, protected Rhizobium from predation by protozoa in a liquid culture and in soil amended with the clay (Heijnen et al., 1991; Heijnen and van Veen, 1991). Bacterial growth and activity were higher in the presence of montmorillonite clays compared with kaolinite clays and oxides (Bitton et al., 1976; Bushby and Marshall, 1977; Stotzky and Rem, 1966). This differential effect is related to the greater cation exchange capacity and surface area of 2:1 clay particles (Stotzky, 1966), which presumably confer greater protection against desiccation (Bitton et al., 1976; Bushby and Marshall, 1977) than 1:1 clays and oxides. Van Gestel et al. (1996), however, suggested that clays do not provide protection against severe drying because water associated with clays is evaporated during drying events. Nevertheless, bacteria were protected in soil aggregates subjected to dry-wet cycles; whereas, fungi were not, presumably because they reside in larger pores and on the surfaces of the aggregates where they are more exposed to drying conditions (Denef et al., 2001).

In addition to soil texture and mineralogy, soil structure and the pore-size distribution within soil aggregates indirectly influence microbial dynamics by restricting organism movement and thereby modifying the interactions between organisms. The diameters of bacteria, fungal hyphae, protozoa, and nematodes are: 0.15 to 4 (although typically $0.5-1 \mu \mathrm{m}), 3$ to 8,10 to 100 , and $<50 \mu \mathrm{m}$, respectively (Coyne, 1999; Killham, 1994). The larger size of fungi relative to bacteria means that fungi are rarely found in micropores (Killham, 1994). However, small pores provide refuges for bacteria against attack from larger predators (i.e., protozoa and bacterivorous nematodes) that are typically unable to enter smaller pores. Spatial differentiation of bacterial community composition has been observed between waterstable microaggregate interiors and macroaggregates (Mummey and Stahl, 2004; Mummey et al., 2005).

The location of bacteria and fungi within the pore network is a key factor in their survival and activity, and the larger size of fungi may make them more vulnerable to predation. Bacterial populations are consistently high in small pores, but highly variable in large pores where they are vulnerable to being consumed (Vargas and Hattori, 1986). For example, Heijnen and van Veen (1991) found that the survival of introduced rhizobia was enhanced in pores smaller than $6 \mu \mathrm{m}$ and negatively affected in pores greater than $6 \mu \mathrm{m}$ in size. Vargas and Hattori (1986) suggested three mechanisms by which aggregates protect microbes against predation: (i) small pore neck sizes exclude protozoa and nematodes from entering, (ii) aggregates are divided into "compartments" and "walls" which limit movement from one part of an aggregate to another and (iii) migration of protozoa and nematodes among aggregates is restricted by the extent that aggregates are connected by a continuous water film. The "compartments" and "walls" of Vargas and Hattori (1986) are considered equivalent to water-filled and airfilled pores, respectively (Elliott and Coleman, 1988).

Two contrasting hypotheses, based on soil matric potential, have been proposed to predict trophic interactions between microfauna and microorganisms. First, the exclusion hypothesis predicts that microbial prey become inaccessible to their microfaunal predators as matric potential decreases because microfauna require water films for movement into pore spaces (Elliott et al., 1980; Savin et al., 2001). For example, bacterial survival in the presence of protozoa was greatest in a bentoniteamended soil with low moisture content $\left(18 \%\right.$, or $-10^{5}$ $\mathrm{Pa}$ ) compared with higher moisture contents (Heijnen and van Veen, 1991). Although air-filled "walls" in aggregates may protect bacteria from grazing, $\mathrm{C}$ turnover and $\mathrm{N}$ mineralization stimulated by grazing may not always decline with soil drying. Kuikman et al. (1989) observed increased ${ }^{15} \mathrm{~N}$-uptake by plants growing in soil in which substantial protozoan grazing on ${ }^{15} \mathrm{~N}$-labeled bacteria occurred, even under strongly fluctuating soil moisture conditions. Although drought stress severely limits protozoan movement into soil pores with porenecks smaller than $3 \mu \mathrm{m}$ (Vargas and Hattori, 1986), protozoa can recover quickly to capitalize on increased bacterial growth once moisture is restored.

In contrast, the enclosure hypothesis predicts that grazing pressure increases when matric potential decreases because microfauna become trapped within water-filled pore spaces in higher densities and in closer proximity to their prey (Gorres et al., 1999; Savin et al., 2001). The latter hypothesis is supported by the observation that $\mathrm{qCO}_{2}$, the amount of $\mathrm{CO}_{2}-\mathrm{C}$ respired per unit microbial biomass $\mathrm{C}$, is positively correlated with the numbers of microbivorous nematodes (predominantly bacteriovores) present at low soil matric potentials $(-50 \mathrm{kPa})$ (Savin et al., 2001). Nematode community composition did not change across four matric potential levels and relatively large nematodes survived in soil with a matric potential of $-50 \mathrm{kPa}$ (Neher et al., 1999). Nematode grazing of bacteria stimulated microbial activity even when nematodes were presumably unable to migrate between water-filled pores, giving further support to the enclosure hypothesis.

The spatial compartmentalization of prey and predators by aggregates can be extended to higher trophic levels. For example, protozoa can access substrates (i.e., bacteria) that are physically unavailable to nematodes, but then are themselves consumed by nematodes (Elliott et al., 1980). Carbon and $\mathrm{N}$ mineralization are often stimulated in the presence of grazers compared to when they are absent (Chen and Ferris, 1999). Hence, if an aggregated soil has more habitable pore space for protozoa and fungi in which they are protected from nematode predation, then $\mathrm{C}$ and $\mathrm{N}$ mineralization will likely be reduced. 
Size differentiation between fungi and bacteria may contribute to differences in degree of protection from predation, and this degree of protection likely differs between soils depending on clay content and type. If the only difference between fungi and bacteria were that fungi are less protected, and therefore more available for consumption, we might expect to see more $\mathrm{CO}_{2}$ evolved and less $\mathrm{C}$ sequestered in fungi-dominated soils. However, other factors such as MGE and chemical recalcitrance of MOM also contribute to overall soil C sequestration (Fig. 1, Steps I and II). More research into how clay type and clay content differentially impact protection of bacterial vs. fungal biomass is needed.

\section{Microbial Growth Efficiency}

During SOM decomposition, heterotrophic microorganisms partition substrate $C$ between biomass synthesis and respiration. Microbial growth efficiency is the amount of new biomass $\mathrm{C}$ produced per unit substrate $\mathrm{C}$ metabolized and determines the amount of substrate $\mathrm{C}$ that will be lost from the soil as $\mathrm{CO}_{2}$. Obtaining accurate estimates of MGE is of interest not only for understanding microbial growth and metabolism, but also for input into ecosystem level SOM budgets and simulation models. For example, the Century SOM model assumes that $55 \%$ of the $\mathrm{C}$ assimilated by the microbial biomass is lost as $\mathrm{CO}_{2}$ when nonlignin SOM pools are decomposed, compared with $45 \%$ for non-lignin surface litter (Parton et al., 1987). These parameter values are based on the assumption that fungi are the primary decomposers of surface litter and that fungi have a higher MGE than bacteria, leading to greater $\mathrm{C}$ stabilization in microbial biomass when surface litter versus SOM is decomposed (Parton et al., 1987). A sensitivity analysis of the model indicated that modest changes in MGE have a significant effect on $\mathrm{C}$ and $\mathrm{N}$ dynamics (Keith Paustian, personal communication, 2005).

Measuring MGE in soil is difficult and most of the available data are from laboratory culture experiments or studies in aquatic systems (Table 1). There is wide variability in reported MGE estimates, ranging from a low of $0.01 \mathrm{~g}$ microbial- $\mathrm{C} \mathrm{g}^{-1}$ metabolized-C to a high of 0.85 (i.e., only $15 \%$ lost as $\mathrm{CO}_{2}$ ) (Table 1 ). Variability in MGE estimates has been attributed to temperature (Rivkin and Legendre, 2001; Seto and Misawa, 1982), salinity (reviewed by del Giorgio and Cole, 1998), pH (Seto and Noda, 1982), substrate quality and quantity (Bremer and Kuikman, 1994; Shen and Bartha, 1996), and nutrient availability (reviewed by del Giorgio and Cole, 1998); the latter two appear to be the most important factors regulating MGE. Microbial efficiency tends to decline as substrate complexity increases and as nutrients, particularly $\mathrm{N}$, become limiting. However, del Giorgio and Cole (1998) noted that, at least for aquatic systems, there are numerous examples where nutrient availability is not well correlated with MGE.

Variability in MGE estimates may also be attributable, in part, to the use of different methodologies, each approach being based on a different set of assumptions (Frey et al., 2001). For example, MGE will be signifi-
Table 1. Summary of studies on bacterial and fungal growth efficiency.

\begin{tabular}{|c|c|c|c|}
\hline Study & Bacteria & Fungi & Mixed \\
\hline \multicolumn{4}{|c|}{$\begin{array}{l}\text { g microbi } \\
\text { Laboratory cultures }\end{array}$} \\
\hline $\begin{array}{l}\text { Waksman, 1929† } \\
\text { Payne, 1970 } \\
\text { Harley, 1971 } \dagger \\
\text { Lindeberg and Lindeberg, } 1977 \\
\text { Payne and Wiebe, 1978 } \\
\text { Lekkerkerk et al., 1990 } \\
\text { Schrickx et al., 1993 } \\
\text { Baroglio et al., } 2000\end{array}$ & $\begin{array}{l}0.20-0.40 \\
0.56-0.68 \\
0.04-0.85\end{array}$ & $\begin{array}{l}0.30-0.50 \\
0.61 \\
0.40-0.70 \\
0.30-0.40 \\
\\
0.10-0.26 \\
0.53-0.62 \\
0.05-0.57\end{array}$ & \\
\hline \multicolumn{4}{|c|}{ Aquatic systems } \\
\hline $\begin{array}{l}\text { del Giorgio and Cole, } 1998 \\
\text { Suberkropp, } 1991 \\
\text { Søndergaard et al., } 2000 \\
\text { Rivkin and Legendre, } 2001 \S\end{array}$ & $\begin{array}{l}0.01-0.60 \\
0.43 \\
0.10-0.70\end{array}$ & $0.15-0.23$ & \\
\hline \multicolumn{4}{|c|}{ Sterile soil inoculated with a single organism } \\
\hline $\begin{array}{l}\text { Anderson et al., } 1981 \\
\text { Elliott et al., } 1983\end{array}$ & $\begin{array}{l}0.60 \\
0.61\end{array}$ & & \\
\hline \multicolumn{4}{|c|}{ Non-sterile soil with a mixed population } \\
\hline Shields et al., 1973 & & & 0.63 \\
\hline Behera and Wagner, 1974 & & & $\mathbf{0 . 3 9}$ \\
\hline Adu and Oades, 1978a & & & 0.58 \\
\hline Anderson and Domsch, 1986 & & & $0.37-0.53$ \\
\hline Schimel, 1988I & & & $\begin{array}{l}0.25-0.59 \\
0.54-0.73\end{array}$ \\
\hline $\begin{array}{l}\text { Parsons and Smith, } 1989 \\
\text { Ladd et al., } 1992\end{array}$ & & & $\begin{array}{l}0.54-0.73 \\
0.50-0.77\end{array}$ \\
\hline Bremer and Kuikman, 1994 & & & $0.58-0.70$ \\
\hline Hart et al. 1994 I & & & $0.14-0.60$ \\
\hline Shen and Bartha, 1996 & & & $0.47-0.66$ \\
\hline Dahlin and Witter, 1998 & & & $0.45-0.53$ \\
\hline Frey et al., 2001 & & & $0.26-0.68$ \\
\hline Lundberg et al., 2001 & & & $0.60-0.74$ \\
\hline
\end{tabular}

$\dagger$ No data or citations are presented and it is unclear as to the growth conditions under which these yield values were obtained.

$\uparrow$ Literature review of growth yield and efficiency under controlled laboratory conditions. The range of yield values reported here was obtained under a variety of growth conditions, including differences in $\mathrm{pH}$, temperature, and substrate quality and quantity.

$\S$ Comprehensive literature review on bacterial growth efficiency in oceans. II Estimated from ${ }^{15} \mathrm{~N}$ immobilization data.

cantly underestimated if (i) estimates are based on changes in microbial biomass in response to substrate addition and (ii) simultaneous biomass consumption by grazers (e.g., protozoa) is not accounted for (Frey et al., 2001). Microbial efficiency may also be underestimated if maintenance requirements are ignored or if experiments are not terminated before substrate recycling begins to occur, thereby artificially inflating observed $\mathrm{CO}_{2}$ losses (Chapman and Gray, 1986).

Wardle and Ghani (1995) suggested that $\mathrm{qCO}_{2}$ is a useful measure of microbial efficiency. In agreement with this idea, Sakamoto and Oba (1994) and Blagodatskaya and Anderson (1998) found a negative correlation between fungal:bacterial biomass ratio and $\mathrm{qCO}_{2}$. Additionally, Miller and Dick (1995) found lower $\mathrm{qCO}_{2}$ values in macroaggregates $(>0.25 \mathrm{~mm})$, which also have higher amounts of fungal biomass than microaggregates $(<0.25 \mathrm{~mm})$ (Gupta and Germida, 1988). These observations have been taken as indirect evidence to support the concept that soil fungi are more efficient than bacteria in their utilization of substrate. This paradigm has a strong hold in soil ecology (e.g., Alexander, 1977; Holland and Coleman, 1987; Rillig et al., 1999; Zak et al., 1996); however, there are equally plausible alter- 
nate explanations for the observed negative relationship between $\mathrm{qCO}_{2}$ and fungal biomass. For example, fungaldominated communities may utilize less substrate per unit of measured biomass (thus lower respiration), or active biomass may be overestimated in fungal-dominated communities because many of the hyphae measured by microscopy to estimate biomass may be inactive. Further, without quantifying how much substrate was utilized by the microbial community for the time period over which respiration and biomass measurements are made, or how much $\mathrm{CO}_{2}$ is respired per unit new biomass, it is impossible to determine the relative partitioning between biomass production and respiration losses, a necessary requisite for calculating MGE. For these reasons, we argue that $\mathrm{qCO}_{2}$ is not an appropriate measure of microbial efficiency and suggest that new approaches for measuring MGE in soils need to be developed.

Based on the assumption of higher fungal MGE, it has been hypothesized that more MOM will be formed in less disturbed systems (such as no-tillage soils and abandoned agricultural soils) where fungi represent a higher proportion of the total microbial biomass (Beare et al., 1992; Holland and Coleman, 1987; Allison et al., 2005). This hypothesis that fungi have higher MGE has been in the literature for decades, yet there is little supporting evidence, and rigorous in situ testing is required. Namely, if fungi are more efficient than bacteria, then one would expect MGE values to be highest for purely fungal communities, medium for mixed communities, and lowest for purely bacterial communities; however, there is significant overlap in the range of reported MGE values for these groups based on laboratory culture studies (Table 1). Efficiency values reported for soils have usually been obtained by amending soil containing a mixed microbial population with a simple substrate, usually glucose. Since most of these studies do not report the relative abundance/biomass of bacteria and fungi, it is impossible to attribute observed differences in MGE to differences in fungal:bacterial ratios.

To our knowledge, no direct measurements of the production efficiency of microbial communities differing in fungal:bacterial biomass ratios have been made. In response to this need, Thiet et al. (2005) measured MGE in fungal- and bacterial-dominated soils directly using ${ }^{13} \mathrm{C}$-glucose substrate and two different levels of $\mathrm{N}$ amendment. No differences were found in MGE between fungal- and bacterial-dominated soils at either $\mathrm{N}$ level. Microbial growth efficiency of fungal- and bacterialdominated soils was 69 and $70 \%$, respectively, when soils were not amended with $\mathrm{N}$, and 78 and $76 \%$ when $\mathrm{N}$ was added.

Based on current knowledge of fungal and bacterial MGE, we conclude that there is little to no support for the hypothesis that fungi have a greater MGE than bacteria. However, it is known that the relative biomass of fungi comprises the majority of soil microbial biomass in natural ecosystems and no-till agricultural systems (Beare et al., 1992; Holland and Coleman, 1987; Frey et al., 1999). Fungal cells typically have a $\mathrm{C} / \mathrm{N}$ ratio of about 10 while bacteria have a $\mathrm{C} / \mathrm{N}$ of about 4 (Sylvia et al., 2005); thus, for a given amount of microbial biomass, fungal biomass contains more $\mathrm{C}$ per unit $\mathrm{N}$ than bacterial biomass. Consequently, fungal biomass is represented in Fig. 1 as a larger pool because a greater proportion of $\mathrm{C}$ is retained in fungal rather than bacterial biomass, assuming that this biomass has the same level of protection.

\section{DEGRADATION OF MICROBIALLY DERIVED SOIL ORGANIC MATTER}

In this section, we focus on the chemical composition, location, and decomposition of bacteria- and fungusderived MOM in the soil (Fig. 1, Step II). Once a C substrate is incorporated into microbial biomass, this newly synthesized material is a potential substrate for other soil microorganisms. The rate and extent to which microbial products are subsequently decomposed is determined within a given environment by the chemical composition and physical location of the material within the soil matrix. However, before discussing the degradation of MOM, we summarize the techniques used to determine MOM, a poorly defined SOM pool.

\section{Chemical Extraction of Microbial-Derived Soil Organic Matter}

The amount of MOM is often estimated by proxies such as carbohydrate extractions by acid hydrolysis or hot water extraction and by examining the ratio of (galactose + mannose $) /($ arabinose + xylose $)($ Oades, 1984) Microorganisms produce polysaccharides which contain little arabinose and xylose; whereas, plant polysaccharides contain little galactose and mannose (Cheshire, 1977; Oades, 1984). Hot water-extractable carbohydrates are reportedly more microbially derived than acid hydrolyzable carbohydrates (Angers et al., 1993; Ball et al., 1996; Cheshire, 1977; Haynes and Francis, 1993).

Soil amino sugar concentration has also been proposed as a proxy of the microbial contribution to SOM accumulation and turnover. Higher plants do not synthesize significant amounts of amino sugars, while bacteria and fungi do (Benzing-Purdie, 1984; Chantigny et al., 1997; Zhang and Amelung, 1996). Glucosamine and muramic acid are of special interest because while glucosamine is found in bacterial and fungal cell walls and the exoskeletons of microarthropods, muramic acid uniquely originates from bacteria (Chantigny et al., 1997). Since the biomass of soil invertebrates is low relative to microbial biomass and the muramic acid to glucosamine ratio is approximately 1 in bacterial cell walls, the ratio of glucosamine to muramic acid can be used to differentiate between fungal and bacterial contributions to MOM (Chantigny et al., 1997; Guggenberger et al., 1999; Six et al., 2001; Zelles, 1988; Simpson et al., 2004).

Measurements of other $\mathrm{C}$ compounds have also been used to determine the relative fungal and bacterial contributions to soil C. Solid state cross polarization/magic angle spinning ${ }^{13} \mathrm{C}$ NMR spectroscopy of selectively cultured bacteria and fungi has been employed to try differentiating fungal versus bacterial $\mathrm{C}$ (Baldock et al., 1990a, 1990b; Kogel-Knabner, 2002). Bacterial C is 
dominated by alkyl, aromatic, and carboxyl C; whereas, fungal $\mathrm{C}$ contains more $\mathrm{O}$-alkyl and acetal groups. In addition, insoluble, non-hydrolyzable aliphatic biomacromolecules, termed bacteran, are found in bacteria and are believed to have a high potential for accumulation in soils (Kogel-Knabner, 2002). Likewise, it has often been suggested that melanins, found in fungi, form a precursor for SOM formation (Linhares and Martin, 1978), but the large differences in structural composition of fungal melanins (Knicker et al., 1995) lead to great differences in their stability in soils (Kogel-Knabner, 2002). Wright et al. (1996) extracted the glycoprotein, glomalin, produced by hyphae of arbuscular mycorrhizal fungi, using a citrate extraction. Glomalin is abundant in a range of soils and positively correlated with the percentage of water-stable aggregates (Wright and Upadhyaya, 1996). Chenu (1989) observed a strong water-stabilizing effect of a fungal polysaccharide, scleroglucan, the effect of which was attributed to an increased strength of interparticle bonds (Chenu and Guerif, 1991).

\section{Physical Fractionation of Microbially Derived Soil Organic Matter Pools}

Since SOM dynamics are closely related to soil structural properties (Oades, 1984), there have been numer- ous attempts to physically isolate SOM pools that contain a high proportion of MOM-C. Chemical characterization of the LF, isolated by density flotation, indicates the predominantly plant-derived nature of this fraction; however, traces of glucosamine and muramic acid have also been detected in this fraction (Six et al., 2001). The heavy fraction is enriched in MOM-C (Roberson et al., 1995), but plant-derived $C$ is also always present.

In addition to density fractionation techniques, particlesize separations have been applied to isolate SOM fractions that contain a high proportion of MOM. The clay fraction reportedly is more enriched in MOM-C than silt and sand particles (Baldock et al., 1990c; Cheshire and Mundie, 1981; Guggenberger et al., 1995; Zhang et al., 1998), and mean annual precipitation (MAP) and mean annual temperature (MAT) have been identified as key site variables that determine the accumulation of microbial products in the clay fraction (Amelung et al., 1999a, 1999b; Zhang et al., 1998). For example, glucosamine concentration in the top $5 \mathrm{~cm}$ of grassland soils (Amelung et al., 1999c) was highly significantly and positively related to the percentage of clay and to the natural logarithm of the ratio of MAP over MAT (Fig. 2). However, when the glucosamine concentrations of the entire plow layer $(0-20 \mathrm{~cm})$ of agricultural soils under

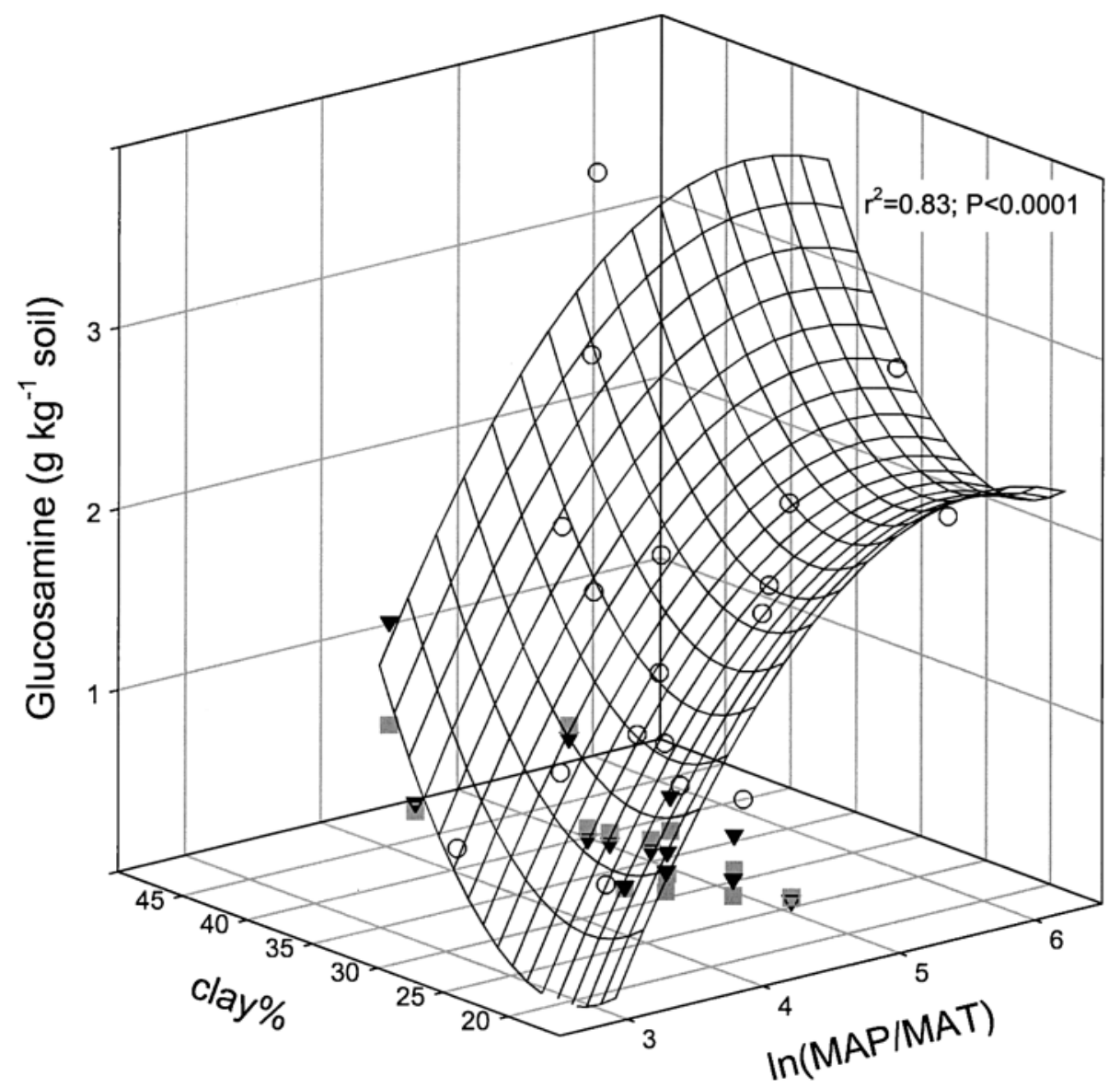

Fig. 2. Glucosamine concentrations $\left(\mathrm{g} \mathrm{kg}^{-1}\right.$ soil) in soil of grassland ecosystems $(\bigcirc)$, no-tillage agroecosystems $(\nabla)$ and conventional tillage agroecosystems ( $\square$ ), and their relationship with percent clay content, mean annual precipitation (MAP), and mean annual temperature (MAT). Data were obtained from Amelung et al. (1999c) for the grassland ecosystems and from Frey et al. (unpublished data) for the agroecosystems (the latter data were not included in the regression). 
no-tillage (NT) and conventional tillage (CT) management were considered, the above relationship was no longer observed (Fig. 2).

While numerous studies have shown an enrichment of MOM-C primarily in the clay fraction, other studies have reported enrichment in the silt fraction. Ladd et al. (1977a, 1977b, 1977c) incubated a calcareous clay and a calcareous sandy soil amended with ${ }^{15} \mathrm{~N}$-labeled glucose and ${ }^{15} \mathrm{~N}$-labeled wheat straw. Organic ${ }^{15} \mathrm{~N}$ was first accumulated in the fine clay fraction; however, after immobilization and mineralization, organic ${ }^{15} \mathrm{~N}$ decreased in the fine clay fraction and increased in the coarse clay and silt fraction. An incubation of a clay soil amended with ${ }^{14} \mathrm{C}$-labeled acetate and $\left({ }^{15} \mathrm{NH}_{4}\right)_{2} \mathrm{SO}_{4}$ revealed a transfer of microbially derived products from an initial accumulation in the $<0.04-\mu \mathrm{m}$ fraction to the coarse clay fraction $(>-0.2 \mu \mathrm{m})$ (McGill et al., 1975). The transfer of $\mathrm{C}$ and $\mathrm{N}$ from fine- to coarse-sized particles probably occurs as resistant cell wall material is formed by successive microbial populations (Ladd et al., 1977b; McGill et al., 1975). Chotte et al. (1998) incubated ${ }^{14} \mathrm{C}$-labeled legume and wheat leaves and observed a bimodal distribution: the majority of the ${ }^{14} \mathrm{C}$-labeled microbial biomass was associated with the silt-sized microaggregates $(2-50 \mu \mathrm{m})$ and the light fraction $(>250 \mu \mathrm{m})$. The residual ${ }^{14} \mathrm{C}$ decreased in the light fraction but increased in the silt fraction with time of incubation. They concluded that plant residues are sites for microbial activity but that the interaction between clay particles and microbial products leads to an accumulation of these products in stable silt-sized microaggregates. JocteurMonrozier et al. (1991) observed the same bimodal distribution of microbial biomass in the coarse- $(>250 \mu \mathrm{m})$ and silt-sized $(2-20 \mu \mathrm{m})$ fraction, but the highest concentration of relatively stable organic $\mathrm{C}$ and $\mathrm{N}$ was found in the silt-sized fraction.

Some of the differences among the above-mentioned studies regarding the amount and characteristics of $\mathrm{C}$ in the most enriched size fraction are likely due in part to the different methods used to isolate the size fractions. Particle-size fractions are often obtained following sonication, and the studies reporting the highest enrichment of $\mathrm{C}$ and $\mathrm{N}$ in the clay fraction typically used a higher energy level to disperse the soil than studies reporting the highest enrichment of $\mathrm{C}$ and $\mathrm{N}$ in the silt fraction. The silt fraction of the latter studies is probably very stable silt-sized microaggregates (Oades, 1990).

A more complex fractionation scheme, in which size and density separation techniques were combined, was used by Cambardella and Elliott (1994) to isolate occluded SOM fractions from within the aggregate structure. Fine silt-sized particles isolated from macroaggregates and having a density of 2.07 to $2.22 \mathrm{~g} \mathrm{~cm}^{-3}$ were found to be enriched with labile $\mathrm{C}$ and N. Subsequent studies characterized this fraction as predominately plant and not microbial in origin (Rodionov et al., 2001; Six et al., 2001) and revealed that this fractionation technique cannot easily be extrapolated to soils other than the Mollisol used in the original study (Six et al., 2000c). However, a different study found greater accumulation of fungal $\mathrm{C}$ in microaggregates contained within macroaggregates in NT soil compared with CT soil, due to greater fungal-mediated soil structural stability in NT soil (Simpson et al., 2004).

In summary, depending on the method and soil investigated, an enrichment of MOM is found in the silt or clay fraction; a purely MOM fraction has not been isolated. Size and/or density fractionation is still useful in isolating fractions that contain a high proportion of MOM and, in combination with chemical characterization of the isolated pools, can lead to a better understanding of MOM pool dynamics (Fig. 1, Step II).

\section{Protected versus Unprotected Microbially Derived Soil Organic Matter}

The amount of bacterial and fungal byproducts that accumulate in the soil depends on the chemical composition of the byproducts, as well as on the degree to which these materials are physically protected within the soil matrix. However, the relative importance of chemical recalcitrance versus physical protection for bacterial versus fungal products is unknown. It is generally assumed that fungi produce more chemically recalcitrant metabolites than bacteria. This assumption is based largely on experiments where labeled cell wall materials have been added to soil and their rate of decomposition determined over some incubation period. For example, Nakas and Klein (1979) followed the decomposition of ${ }^{14} \mathrm{C}$-labeled cell walls in a grassland soil and observed that degradation of fungal material was generally lower than material of bacterial origin. Fungal hyphae with a high melanin concentration also decay more slowly than less-melanized forms (Linhares and Martin, 1978; Martin and Haider, 1986). To our knowledge, no studies have been done to examine the fate of bacterial and fungal cells produced and labeled in situ.

Microbial products are protected from decomposition through (i) their interaction with clay and silt particles (i.e., chemical stabilization) and (ii) physical occlusion within stable soil aggregates. Clays provide a protective environment for microbial biomass and likely also for MOM. However, little is known about how clay and silt may provide differential protection of fungus versus bacteria-derived MOM. Puget et al. (1999) found that the silt plus clay fraction of NT and CT soil is enriched in microbially derived carbohydrates. In addition, Guggenberger et al. (1999) found an increased glucosamine/ muramic acid ratio with NT versus CT in soils with a relatively higher silt plus clay content. A re-examination of data presented by Chantigny et al. (1997) indicates that an increased glucosamine/muramic acid ratio in perennial systems compared with annual systems was only observed in a silty clay loam soil but not in a clay loam soil. These data indicate a differential effect of silt and clay on the accumulation of bacterial versus fungal organic matter that should be further investigated.

Fungi are important for aggregate formation and stabilization (Bossuyt et al., 2001; Gupta and Germida, 1988; Tisdall, 1994; Tisdall and Oades, 1982), and aggregates physically protect plant-derived SOM and MOM (Beare et al., 1994; Elliott, 1986; Six et al., 2000a). In NT 
versus CT soils, amino sugars associated with fungal hyphae are significantly higher in NT small macroaggregates due to accumulation of fungal sugars in the microaggregates contained within the macroaggregates (Simpson et al., 2004). Conservation of soil C in NT soils is thus due in part to fungal-mediated aggregate stability. Drying and wetting cycles and other mechanical forces (e.g., tillage) disrupt aggregate structures (Paustian et al., 2000) and release plant-derived organic matter and MOM, thereby hastening the degradation of these SOM pools. Carbon and $\mathrm{N}$ mineralization often increase following aggregate disruption (see Balesdent et al. [2000] and Six et al. [2002] for reviews), a phenomenon attributed to increased bioavailability of SOM released from within the aggregate structure (Adu and Oades, 1978b; Sorensen, 1974).

In summary, the greater presumed biochemical recalcitrance of fungal versus bacterial byproducts leads to a larger fungal $\mathrm{C}$ pool size, represented as a larger box in Fig. 1. Stabilization of MOM via their association with silt and clay particles and physical protection afforded by aggregates are mechanisms leading to the accumulation of soil C. However, the relative importance of each mechanism in terms of protecting fungal versus bacterial $\mathrm{C}$ and overall soil $\mathrm{C}$ sequestration is unknown.

\section{MANAGEMENT EFFECTS ON MICROBIAL BIOMASS AND MICROBIALLY DERIVED SOIL ORGANIC MATTER}

Agricultural management practices differ in the type and intensity of disturbance; therefore, the impact on microbial biomass and MOM varies with the management practice employed. Amounts of microbial biomass are generally highest in undisturbed systems and decline with increasing disturbance, particularly disturbance associated with cultivation. Agricultural systems that favor increased levels of microbial biomass include those associated with increased C inputs (Schnürer et al., 1985), reduced tillage (Beare et al., 1992; Doran, 1987; Frey et al., 1999), retention of crop residues rather than removal by burning (Gupta et al., 1994), and integrated farming systems that combine reduced tillage with increased $\mathrm{C}$ inputs through organic amendments (Hassink et al., 1991).

\section{Crop Rotations}

Crop rotation affects microbial biomass, activity, and fungal:bacterial biomass ratios. Soils under crop rotation show increased soil enzyme activity when compared with soils under continuous monocropping (AcostaMartínez et al., 2003). Microbial biomass levels are typically higher when legume cover crops are included in the rotation than when fields are left fallow between cash crops (Lupwayi et al., 1999). Likewise, microbial biomass and fungal:bacterial biomass ratios were higher in a NT wheat-barley compared with wheat-fallow rotation (Bell et al., 2003). Viable propagules of mycorrhizal fungi (Thompson, 1987) and glomalin concentrations (Wright and Anderson, 2000) have also been observed to decline in rotations that include a fallow period. However, varying crop rotations that include only mycorrhizal crops have minimal to no effect on mycorrhizal colonization (An et al., 1993). Incorporation of forage species into crop rotations increases hot water-extractable carbohydrates (Haynes and Francis, 1993), likely due to higher root inputs and the stimulation of microbial activity that follows (Haynes and Swift, 1990; Haynes and Francis, 1993). Total acid hydrolyzable carbohydrate content, on the other hand, is variably affected by crop rotation and forage species (Oades, 1967; Baldock et al., 1987). Additionally, the proportion of SOM present as acid hydrolyzable carbohydrates was observed to be constant across differing rotational systems (Baldock et al., 1987; Angers et al., 1993). In contrast, hot water-extractable carbohydrate content was not a constant proportion of total SOM under different crop rotations (Angers et al., 1993; Haynes and Swift, 1990). This indicates that the hot water extractable carbohydrates are more influenced by crop rotations than are acid hydrolyzable carbohydrates. Since hot water extractable carbohydrates are considered more microbially derived than acid hydrolyzable carbohydrates, the microbially derived carbohydrates seem to be more affected by crop rotations than plant-derived carbohydrates. In contrast, Guggenberger et al. (1995) found that the change in carbohydrate content in a native savanna converted to pasture was dominated by a change in carbohydrates associated with the plant-derived SOM in the sand fraction. The same was observed when soils under barley versus alfalfa were compared (Angers and Mehuys, 1990).

To summarize, crop rotation as a management practice may increase soil $\mathrm{C}$ sequestration in comparison with continuous crop management or rotations that include fallow periods. More intensive cropping rotations not only increase soil $\mathrm{C}$ input but also increase microbial activity and biomass and alter microbial community composition, increasing levels of soil fungi.

\section{Tillage}

No-tillage and minimum tillage (MT) systems often exhibit increased C storage compared with CT (Ogle et al., 2003; Six et al., 2002; West and Post, 2002); however, this difference disappears with the use of fallow rotations (Peterson et al., 1998), demonstrating the importance of using multiple management practices to enhance soil $\mathrm{C}$ storage. The greatest differences between NT and CT soils occur in the top $5 \mathrm{~cm}$ with NT soils having greater fungal:bacterial biomass ratios (Beare et al., 1992; Frey et al., 1999), enzyme activity (AcostaMartínez et al., 2003; Bergstrom et al., 2000; Deng and Tabatabai, 1996; Kandeler et al., 1999a), mycorrhizal colonization levels (Drijber et al., 2000; McGonigle et al., 1999; O'Halloran et al., 1986; Vivekanandan and Fixen, 1991), macroaggregation (Six et al., 2000b), total C and N contents (Feng et al., 2003; Hendrix et al., 1986), and concentrations of bacteria- and fungus-derived amino sugars (Guggenberger et al., 1999; Simpson et al., 2004). Differences in tillage intensity also impact microbial 
community composition (Beare, 1997; Doran, 1980; Drijber et al., 2000; Frey et al., 1999; Jackson et al., 2003; Neely et al., 1991). Frey et al. (1999) examined fungal:bacterial biomass ratios at six long-term tillage comparison experiments located along two climatic gradients and observed that fungal biomass and fungal: bacterial biomass ratios increased in response to reduced tillage at all sites. This suggests that a shift toward fungaldominated microbial communities under NT will be most important for residue decomposition and nutrient cycling processes near the soil surface. However, another study found no difference in fungal:bacterial ratio in surface NT and CT soils and a $10 \%$ lower fungal:bacterial ratio in NT soil at 6 to $12 \mathrm{~cm}$ (Feng et al., 2003). Lessintensively managed agroecosystems (e.g., NT) bear the closest resemblance to natural ecosystems, which are fungal-dominated (Bailey et al., 2002; Bardgett, 1996; Bardgett and McAlister, 1999; Yeates et al., 1997). These fungal-dominated agroecosystems require fewer inputs to sustain organic matter decomposition and nutrient cycling, that is, these systems show greater self-regulation (Bardgett and McAlister, 1999; Wardle et al., 1995; Yeates et al., 1997). However, Allison et al. (2005) concluded that an improved metabolic efficiency due to increased relative abundance of arbuscular mycorrhizal fungi (AMF) and saprophytic fungi does not promote the stabilization of $\mathrm{C}$ on cessation of tillage-based agriculture.

Three main factors have been identified as potential controls on bacterial and fungal biomass in NT and CT soils: degree of disturbance, soil moisture content, and residue placement. However, the relative importance of these factors on soil fungal:bacterial biomass ratios in NT soil is unknown. Reduced disturbance in NT systems may favor fungal growth and activity due to enhanced establishment and maintenance of extensive hyphal networks (Wardle, 1995). Thus, NT systems can accumulate fungal pathogens as well as mycorrhizal fungi (Miller and Lodge, 1997). Soil moisture may differentially influence bacteria and fungi either by directly affecting survival and growth or indirectly by shifting substrate availability and microbivore populations. Frey et al. (1999) observed that fungal biomass and fungal:bacterial biomass ratios were positively related to soil moisture in both NT and CT soil. Fungal biomass and relative fungal abundance were not significantly different in NT compared with CT when the data were analyzed by analysis of covariance with soil moisture as the covariate, suggesting that observed tillage treatment effects on the microbial community are related to differences in soil moisture (Frey et al., 1999). Residue placement (surface residues in NT vs. incorporated residues in CT) has also been shown to alter bacterial and fungal populations (Holland and Coleman, 1987; Beare et al., 1992). It was hypothesized that the presence of surface residues favors fungal growth because fungi, unlike bacteria, can bridge the soil-residue interface and simultaneously utilize the spatially separated $\mathrm{C}$ and $\mathrm{N}$ resources by translocating soil inorganic $\mathrm{N}$ into the $\mathrm{C}$-rich surface residues (Beare et al., 1992; Holland and Coleman, 1987). Frey et al. (2000) demonstrated that fungi do have the potential to translocate significant quantities of soil inorganic
$\mathrm{N}$ into decomposing surface residues in NT systems, and that this $\mathrm{N}$ flow increases fungal proliferation in the surface residues themselves. In addition, reciprocal translocation of $\mathrm{C}$ from surface residues to mineral soil via fungal hyphae occurs (Frey et al., 2003). The fungal:bacterial ratio can also be greater due to the greater amount and better quality of SOM in the surface layer of NT systems; the latter being induced by the surface residue layer (Paustian et al., 2000) and the increased root growth in the surface layers of NT systems (Qin et al., 2005; Barzegar et al., 2004). An increased resource availability in soil surface layers has been suggested as the main factor for greater proportions of fungi in the microbial community of surface layer compared with deeper soil horizons (Fierer et al., 2003).

Differential effects of NT and CT on MOM have been observed. Hot water-extractable carbohydrates, acid hydrolyzable carbohydrates, and the relative enrichment of SOM in carbohydrates increased under reduced tillage compared with moldboard plowing (Angers et al., 1993). Arshad et al. (1990) reported increased SOM quality under NT compared with CT: SOM in NT soil contained more acid hydrolyzable carbohydrates, amino acids, and amino sugars, and was more aliphatic and less aromatic. The (galactose + mannose)/(arabinose + xylose) ratio in the whole soil acid hydrolyzable carbohydrate pool increased under NT compared with CT, indicating a higher microbially derived carbohydrate $\mathrm{C}$ pool under NT. Similar enrichment of microbially derived carbohydrates under NT versus CT has been reported by Ball et al. (1996) and Beare et al. (1997). Beare et al. (1997) suggested that the greater proportion of microbial-derived compared with plant-derived carbohydrates under NT compared with CT is due to the relatively higher fungal biomass under NT (Beare, 1997; Frey et al., 1999). This is supported by the observation that the ratio of glucosamine to muramic acid is higher under NT compared with CT and this is due to a higher enrichment of glucosamine (Guggenberger et al., 1999; Simpson et al., 2004). This enrichment of glucosamine in NT systems is also observed in Fig. 2, although not at all sites. In addition, Wright and Anderson (2000) found a significantly higher glomalin concentration under NT than CT management, and $\mathrm{Hu}$ et al. (1995) found that inhibition of fungi by the fungicide Captan (N-Trichloromethylthio-4cyclohexene-1,2-dicarbonximide) only reduced concentrations of soil $\mathrm{C}$ and acid hydrolyzable carbohydrates in NT soils, not CT soils.

The above-mentioned studies clearly indicate that NT induces a higher fungal (saprophytic and mycorrhizal) biomass, which leads to a quantitative and qualitative improvement of SOM. However, the increase in fungal biomass under NT not only leads to an increase of MOM, but may also affect the accumulation of plant-derived C (i.e., particulate organic matter [POM]). Six et al. $(1998,1999)$ suggested that increased macroaggregate turnover in tilled soil is an important mechanism causing a loss of POM and MOM. Fungi are expected to retard macroaggregate turnover due to their positive influence on aggregate stabilization; however, the link between fungal abundance, macroaggre- 
gate turnover, and MOM plus POM has not been directly investigated.

\section{Organic Farming and Cover Crops}

Compared with conventional practices, organic farming practices have been shown to promote higher microbial biomass (Lundquist et al., 1999; Petersen et al., 1997) and to alter microbial community composition (Bossio et al., 1998; Petersen et al., 1997). In an incubation experiment where conventional and organic soils were amended with organic matter and exposed to similar incubation conditions, no differences in microbial biomass $\mathrm{C}$ or substrate-induced respiration were observed (Gunapala et al., 1998). However, differences were observed by the end of the incubation experiment in potentially mineralizable $\mathrm{N}$ (higher in organic soils), bacterivorous nematodes (higher in conventional soils), and fungivorous nematodes (higher in organic soils). Fließbach et al. (2000) found that a biodynamic (organically managed) system had higher microbial biomass than conventionally managed soils, and suggested that organic soils provide greater protection of microbial biomass. Bossio et al. (1998) found that conventionally managed, organic, and low input management systems all had significantly different microbial communities and that organic soils had higher fungal:bacterial biomass ratios than conventionally managed soils.

Organic farming practices frequently employ cover crops, which can change the soil microbial community and have a variable effect on MOM. Different overall microbial community composition was observed in continuous maize versus a maize-Crotalaria grahamianafallow rotation, with and without $\mathrm{P}$ addition (Bünemann et al., 2004). Higher levels of fatty acid biomarkers for fungi and Gram (-) bacteria as well as higher overall microbial biomass were present in the maize- $C$. grahamiana-fallow rotation. Soil from the maize- $C$. grahamiana-fallow rotation also exhibited faster decomposition of added $\mathrm{C}$ substrates. A winter cover crop mix of oats and vetch (Avena sativa $\mathrm{L}$. and Vicia sativa L.) increased microbial biomass $\mathrm{C}$, respiration and $\mathrm{N}$ mineralization and changed the microbial community composition compared with a winter fallow treatment (Schutter and Dick, 2002).

Roberson et al. (1991) found that a permanent grass cover crop significantly increased the acid hydrolyzable heavy fraction carbohydrate content. An investigation of the effect of fertilizer and cover crop $\mathrm{N}$ supply on carbohydrates found that the heavy fraction carbohydrates were more microbially derived than the LF carbohydrates (Roberson et al., 1995). A positive effect of vetch (Vicia dasycarpa L.) and $168 \mathrm{~kg} \mathrm{~N} \mathrm{ha}^{-1}$ fertilizer addition on the heavy fraction carbohydrate content was observed. In contrast, the $280 \mathrm{~kg} \mathrm{~N} \mathrm{ha}^{-1}$ fertilizer rate and the oat (Avena sativa L.) cover crop reduced the heavy fraction carbohydrate content compared with a control. A variable effect of cover crops on carbohydrate content was also observed by Kuo et al. (1997). They concluded that the cover crop effect on carbohydrate content was related to the $\mathrm{C}$ inputs from the cover crops. However, Roberson et al. (1995) suggested that the $\mathrm{N}$ supply-more than $\mathrm{C}$ supply-controls the effect of cover crops on soil carbohydrate content.

More research is needed to investigate relationships between the use of organic farming practices (including cover crops) and soil microbial communities. Organic management appears to increase fungal biomass, which would favor increased soil C sequestration (Fig. 1, Step I). Further study is also required to attain a greater understanding of the effects of cover crops and nitrogen additions on microbially derived soil carbohydrates.

\section{SUMMARY}

Changes in the relative abundance and activity of bacteria and fungi may significantly affect $\mathrm{C}$ cycling and storage, due to the unique physiologies and differential interactions with soil physical properties of these two microbial groups. It has been hypothesized that $\mathrm{C}$ turnover is slower in fungal-dominated communities in part because fungi incorporate more soil $\mathrm{C}$ into biomass than bacteria and because fungal cell walls are more recalcitrant than bacterial cell walls. Both of these mechanisms for greater accumulation of fungal SOM warrant further study; however, there is currently little to no support for the idea that fungi have a higher $\mathrm{C}$ utilization efficiency than do bacteria. More information is also needed on the relative turnovers of bacterial versus fungal byproducts under field conditions.

The protection of microbial biomass in soils is related to the reactive surface properties of clays, but the influence of clay type on the protection of microbial biomass in situ is unknown. In addition, the relative influence of disturbance, soil moisture, and residue placement on microbial biomass and community structure should be further investigated.

Microbially derived organic matter is often isolated by chemical extraction (e.g., hot water extraction, amino sugar analysis), or physical fractionation techniques, but the latter have been less successful. The three mechanisms for stabilization of MOM are: biochemical stabilization, chemical stabilization, and physical protection. However, the relative importance of these three mechanisms in terms of $\mathrm{C}$ sequestration is unknown. Biochemical and chemical stabilization seems to differ between fungal versus bacterial $\mathrm{C}$ and should be further investigated in situ.

Fungal extracellular polysaccharides and hyphae are primarily responsible for the formation of soil macroaggregates, which protect plant-derived SOM and MOM. Organic material bound in aggregates decomposes more slowly. Thus, ecosystems with fungal-dominated soil communities (e.g., NT) may have higher $\mathrm{C}$ retention than soil communities dominated by bacterial pathways of decomposition (e.g., CT) due to differences in fungal-mediated aggregate turnover.

Microbial biomass and community composition as well as MOM concentrations are affected by crop rotations, tillage, organic farming practices, and cover crops. All of these management regimes appear to induce shifts in overall microbial community composition and 
fungal:bacterial biomass ratios. Under NT, especially, higher fungal biomass levels are correlated with quantitative and qualitative improvements in SOM. Crop rotations increase levels of microbially derived soil carbohydrates while cover crops have variable effects on MOM.

Shifts in microbial community structure due to soil disturbance have important implications for ecosystemscale processes because bacteria and fungi function differently in the incorporation and turnover of $\mathrm{C}$ and in their respective effects on soil physical properties. Integration of data characterizing soil microbial community composition and activity into ecosystem models of $\mathrm{C}$ and $\mathrm{N}$ cycling will improve our understanding of the relationship between microbial community structure and ecosystem functions such as $\mathrm{C}$ sequestration.

\section{ACKNOWLEDGMENTS}

We thank David Coleman, Donald Zak, and two anonymous reviewers for comments on an earlier version of this manuscript. This project was supported by National Research Initiative Competitive Grant no. 2001-35107-12975 to S.D. Frey and J. Six from the USDA Cooperative State Research, Education, and Extension Service. Funding was also provided by the Consortium for Agricultural Soils Mitigation of Greenhouse Gases (CASMGS).

\section{REFERENCES}

Acosta-Martínez, V., T.M. Zobeck, T.E. Gill, and A.C. Kennedy. 2003. Enzyme activities and microbial community structure in semiarid agricultural soils. Biol. Fertil. Soils 38:216-227.

Adu, J.K., and J.M. Oades. 1978a. Utilization of organic materials in soil aggregates by bacteria and fungi. Soil Biol. Biochem. 10: $117-122$.

Adu, J.K., and J.M. Oades. 1978b. Physical factors influencing decomposition of organic materials in soil aggregates. Soil Biol. Biochem. 10:109-115.

Alexander, M. 1977. Introduction to soil microbiology. John Wiley \& Sons, New York.

Allison, V.J., R.M. Miller, J.D. Jastrow, R. Matamala, and D.R. Zak. 2005. Changes in soil microbial community structure in a tallgrass prairie chronosequence. Soil Sci. Soc. Am. J. 69:1412-1421.

Amato, M., and J.N. Ladd. 1992. Decomposition of ${ }^{14} \mathrm{C}$-labelled glucose and legume material in soils: Properties influencing the accumulation of organic residue $\mathrm{C}$ and microbial biomass C. Soil Biol. Biochem. 24:455-464.

Amelung, W., K.W. Flach, and W. Zech. 1999a. Lignin in particle size fractions of native grassland soils as influenced by climate. Soil Sci. Soc. Am. J. 63:1222-1228.

Amelung, W., K.W. Flach, and W. Zech. 1999b. Neutral and acidic sugars in particle-size fractions as influenced by climate. Soil Sci. Soc. Am. J. 63:865-873.

Amelung, W., X. Zhang, K.W. Flach, and W. Zech. 1999c. Amino sugars in native grassland soils along a climosequence in North America. Soil Sci. Soc. Am. J. 63:86-92.

An, Z.-Q., J.W. Hendrix, D.E. Hershman, R.S. Ferriss, and G.T. Henson. 1993. The influence of crop rotation and soil fumigation on a mycorrhizal fungal community associated with soybean. Mycorrhyza 3:171-182.

Anderson, R.V., D.C. Coleman, C.V. Cole, and E.T. Elliott. 1981. Effect of the nematodes Acrobeloides sp. and Mesodiplogaster lheritieri on substrate utilization and nitrogen and phosphorous mineralization in soil. Ecology 62:549-555.

Anderson, T.-H., and K.H. Domsch. 1986. Carbon assimilation and microbial activity in soil. Z. Pflanzenernaehr. Bodenkd. 149:457-468.

Angers, D.A., and G.R. Mehuys. 1990. Barley and alfalfa cropping effects on carbohydrate contents of a clay soil and its size fractions. Soil Biol. Biochem. 22:285-288.
Angers, D.A., N. Bissonnette, A. Legere, and N. Samson. 1993. Microbial and biochemical changes induced by rotation and tillage in a soil under barley production. Can. J. Soil Sci. 73:39-50.

Arshad, M.A., M. Schnitzer, D.A. Angers, and J.A. Ripmeester. 1990 Effects of till versus no till on the quality of soil organic matter. Soil Biol. Biochem. 22:595-599.

Bailey, V.L., J.L. Smith, and H. Bolton, Jr. 2002. Fungal-to-bacterial ratios in soils investigated for enhanced $\mathrm{C}$ sequestration. Soil Biol. Biochem. 34:997-1007.

Baldock, J.A., B.D. Kay, and M. Schnitzer. 1987. Influence of cropping treatments on the monosaccharide content of the hydrolysates of a soil and it's aggregate fractions. Can. J. Soil Sci. 67:489-499.

Baldock, J.A., J.M. Oades, A.M. Vassallo, and M.A. Wilson. 1990a. Significance of microbial activity in soils as demonstrated by solidstate ${ }^{13} \mathrm{C}$ NMR. Environ. Sci. Technol. 24:527-530.

Baldock, J.A., J.M. Oades, A.M. Vassallo, and M.A. Wilson. 1990b. Solid-state CP/MAS ${ }^{13} \mathrm{C}$ N.M.R. Analysis of bacterial and fungal cultures isolated from a soil incubated with glucose. Aust. J. Soil Res. 28:213-225.

Baldock, J.A., J.M. Oades, A.M. Vassallo, and M.A. Wilson. 1990c Solid State CP/MAS ${ }^{13}$ C N.M.R. Analysis of particle size and density fractions of a soil incubated with uniformly labeled ${ }^{13} \mathrm{C}$-glucose. Aust. J. Soil Res. 28:193-212.

Balesdent, J., C. Chenu, and M. Balabane. 2000. Relationship of soil organic matter dynamics to physical protection and tillage. Soil Tillage Res. 53:215-230.

Ball, B.C., M.V. Cheshire, E.A.G. Robertson, and E.A. Hunter. 1996. Carbohydrate composition in relation to structural stability, compactibility and plasticity of two soils in a long-term experiment. Soil Tillage Res. 39:143-160.

Bardgett, R.D. 1996. Potential effects on the soil mycoflora of changes in the UK agricultural policy for upland grasslands. p. 163-183. In J. C. Frankland et al. (ed.) Fungi and environmental change. Cambridge Univ. Press, Cambridge.

Bardgett, R.D., and E. McAlister. 1999. The measurement of soil fungal:bacterial biomass ratios as an indicator of ecosystem selfregulation in temperate meadow grasslands. Biol. Fertil. Soils 29: 282-290.

Bardgett, R.D., P.J. Hobbs, and Å. Frostegård. 1996. Changes in soil fungal:bacterial biomass ratios following reductions in the intensity of management of an upland grassland. Biol. Fertil. Soils 22: 261-264.

Bardgett, R.D., D.A. Wardle, and G.W. Yeates. 1998. Linking aboveground and below-ground interactions: How plant responses to foliar herbivory influence soil organisms. Soil Biol. Biochem. 30: 1867-1878.

Bardgett, R.D., R.D. Lovell, P.J. Hobbs, and S.C. Jarvis. 1999. Seasonal changes in soil microbial communities along a fertility gradient of temperate grasslands. Soil Biol. Biochem. 31:1021-1030.

Baroglio, C., F. Bosco, and V. Specchia. 2000. Biomass production of the mycorrhizal fungus Suillus grevillei: Effect of $\mathrm{pH}$ and ammonium. Microbios 103:163-177.

Barzegar, A.R., M.H. Mossavi, M.A. Asoodar, and S.J. Herbert. 2004 Root mass distribution of winter wheat as influenced by different tillage systems in semi arid region. J. Agron. 3:223-228.

Beare, M.H. 1997. Fungal and bacterial pathways of organic matter decomposition and nitrogen mineralization in arable soils p. 37-70. In L. Brussaard and R. Ferrera-Cerrato (ed.) Soil ecology in sustainable agricultural systems. Lewis Publishers, Boca Raton, FL.

Beare, M.H., M.L. Cabrera, P.F. Hendrix, and D.C. Coleman. 1994. Aggregate-protected and unprotected organic matter pools in conventional- and no-tillage soils. Soil Sci. Soc. Am. J. 58:787-795.

Beare, M.H., S. Hu, D.C. Coleman, and P.F. Hendrix. 1997. Influences of mycelial fungi on soil aggregation and organic matter storage in conventional and no-tillage soils. Appl. Soil Ecol. 5:211-219.

Beare, M.H., R.W. Parmelee, P.F. Hendrix, W. Cheng, D.C. Coleman, and D.A. Grossley, Jr. 1992. Microbial and faunal interactions and effects on litter nitrogen and decomposition in agroecosystems. Ecol. Monogr. 62:569-591.

Behera, B., and G.H. Wagner. 1974. Microbial growth rate in glucoseamended soil. Soil Sci. Soc. Am. Proc. 38:591-594.

Bell, J.M., J.L. Smith, V.L. Bailey, and H. Bolton. 2003. Priming effect and $\mathrm{C}$ storage in semi-arid no-till spring crop rotations. Biol. Fertil. Soils 37:237-244. 
Benzing-Purdie, L. 1984. Amino sugar distribution in four soils as determined by high resolution gas chromatography. Soil Sci. Soc. Am. J. 48:219-222.

Bergstrom, D.W., C.M. Monreal, A.D. Tomlin, and J.J. Miller. 2000. Interpretation of soil enzyme activities in a comparison of tillage practices along a topographic and textural gradient. Can. J. Soil Sci. 80:71-79.

Bitton, G., Y. Henis, and N. Lahav. 1976. Influence of clay minerals, humic acid and bacterial capsular polysaccharide on the survival of Klebsiella aerogenes exposed to drying and heating in soils. Plant Soil 45:65-74.

Blagodatskaya, E.V., and T.H. Anderson. 1998. Interactive effects of $\mathrm{pH}$ and substrate quality on the fungal-to-bacterial ratio and $\mathrm{qCO}_{2}$ of microbial communities in forest soils. Soil Biol. Biochem. 30:1269-1274.

Bossio, D.A., K.M. Scow, N. Gunapala, and K.J. Graham. 1998. Determinants of soil microbial communities: Effects of agricultural management, season, and soil type on phospholipid fatty acid profiles. Microb. Ecol. 36:1-12.

Bossuyt, H., K. Denef, J. Six, S.D. Frey, R. Merckx, and K. Paustian. 2001. Influence of microbial populations and residue quality on aggregate stability. Appl. Soil Ecol. 16:195-208.

Bremer, E., and P. Kuikman. 1994. Microbial utilization of ${ }^{14} \mathrm{C}[\mathrm{U}] \mathrm{glu}-$ cose in soil is affected by the amount and timing of glucose additions. Soil Biol. Biochem. 26:511-517.

Bünemann, E.K., D.A. Bossio, P.C. Smithson, E. Frossard, and A. Oberson. 2004. Microbial community composition and substrate use in a highly weathered soil as affected by crop rotation and $\mathrm{P}$ fertilization. Soil Biol. Biochem. 36:889-901.

Bushby, H.V.A., and K.C. Marshall. 1977. Water status of rhizobia in relation to their susceptibility to desiccation and to their protection by montmorillonite. J. Gen. Microbiol. 99:19-27.

Cambardella, C.A., and E.T. Elliott. 1994. Carbon and nitrogen dynamics of soil organic matter fractions from cultivated grassland soils. Soil Sci. Soc. Am. J. 58:123-130.

Chantigny, M.H., D.A. Angers, D. Prevost, L.-P. Vezina, and F.-P. Chalifour. 1997. Soil aggregation and fungal and bacterial biomass under annual and perennial cropping systems. Soil Sci. Soc. Am. J. 61:262-267.

Chapman, S.J., and T.R.G. Gray. 1986. Importance of cryptic growth, yield factors and maintenance energy in models of microbial growth in soil. Soil Biol. Biochem. 18:1-4.

Chen, J., and H. Ferris. 1999. The effects of nematode grazing on nitrogen mineralization during fungal decomposition of organic matter. Soil Biol. Biochem. 31:1265-1279.

Chenu, C. 1989. Influence of a fungal polysaccharide scleroglucan, on clay microstructures. Soil Biol. Biochem. 21:299-305.

Chenu, C., and J. Guerif. 1991. Mechanical strength of clay minerals as influenced by an adsorbed polysaccharide. Soil Sci. Soc. Am. J. 55:1076-1080.

Cheshire, M.V. 1977. Origins and stability of soil polysaccharide. J. Soil Sci. 28:1-10.

Cheshire, M.V., and C.M. Mundie. 1981. The distribution of labeled sugars in soil particle size fractions as a means of distinguishing plant and microbial carbohydrate residues. J. Soil Sci. 32:605-618.

Chotte, J.L., J.N. Ladd, and M. Amato. 1998. Sites of microbial assimilation, and turnover of soluble and particulate ${ }^{14} \mathrm{C}$-labelled substrates decomposing in a clay soil. Soil Biol. Biochem. 30: 205-218.

Cole, C.V., J. Duxbury, J. Freney, O. Heinemeyer, K. Minami, A. Mosier, K. Paustian, N. Rosenberg, N. Sampson, D. Sauerbeck, and Q. Zhao. 1997. Global estimates of potential mitigation of greenhouse gas emissions by agriculture. Nutr. Cycl. Agroecosyst. 49: 221-228.

Coyne, M.S. 1999. Soil microbiology: An exploratory approach. Delmar Publishers, Albany, NY.

Dahlin, S., and E. Witter. 1998. Can the low microbial biomass C-toorganic $\mathrm{C}$ ratio in an acid and a metal contaminated soil be explained by differences in the substrate utilization efficiency and maintenance requirements? Soil Biol. Biochem. 30:633-641.

del Giorgio, P.A., and J.J. Cole. 1998. Bacterial growth efficiency in natural aquatic systems. Annu. Rev. Ecol. Syst. 29:503-541.

Denef, K., J. Six, H. Bossuyt, S.D. Frey, E.T. Elliott, R. Merckx, and K. Paustian. 2001. Influence of dry-wet cycles on the interrelationship between aggregate, particulate organic matter, and microbial community dynamics. Soil Biol. Biochem. 33:1599-1611.

Deng, S.P., and M.A. Tabatabai. 1996. Effect of tillage and residue management on enzyme activities in soils I. Amidohydrolases. Biol. Fert. Soils 22:202-207.

Doran, J.W. 1980. Microbial changes associated with residue management with reduced tillage. Soil Sci. Soc. Am. J. 44:518-523.

Doran, J.W. 1987. Microbial biomass and mineralizable nitrogen distributions in no-tillage and plowed soils. Biol. Fertil. Soils 5:68-75.

Drijber, R.A., J.W. Doran, A.M. Parkhurst, and D.J. Lyon. 2000. Changes in soil microbial community structure with tillage under long-term wheat-fallow management. Soil Biol. Biochem. 32: $1419-1430$.

Elliott, E.T. 1986. Aggregate structure and carbon, nitrogen, and phosphorus in native and cultivated soils. Soil Sci. Soc. Am. J. 50:627-633.

Elliott, E.T., and D.C. Coleman. 1988. Let the soil work for us. Ecol. Bull. 39:23-32.

Elliott, E.T., R.V. Anderson, D.C. Coleman, and C.V. Cole. 1980. Habitable pore space and microbial trophic interactions. Oikos 35:327-335.

Elliott, E.T., C.V. Cole, B.C. Fairbanks, L.E. Woods, R.J. Bryant, and D.C. Coleman. 1983. Short-term bacterial growth, nutrient uptake, and ATP turnover in sterilized, inoculated and C-amended soil: The influence of N availability. Soil Biol. Biochem. 15:85-91.

Feng, Y., A.C. Motta, D.W. Reeves, C.H. Burmester, E. van Santen, and J.A. Osborne. 2003. Soil microbial communities under conventional-till and no-till continuous cotton systems. Soil Biol. Biochem. 35:1693-1703.

Fierer, N., A.S. Allen, J.P. Schimel, and P.A. Holden. 2003. Controls on microbial $\mathrm{CO}_{2}$ production: A comparison of surface and subsurface soil horizons. Global Change Biol. 9:1322-1332.

Fließbach, A., P. Mäder, and U. Niggli. 2000. Mineralization and microbial assimilation of ${ }^{14} \mathrm{C}$-labeled straw in soils of organic and conventional agricultural systems. Soil Biol. Biochem. 32:1131-1139.

Franzluebbers, A.J., R.L. Haney, F.M. Hons, and D.A. Zuberer. 1996. Active fractions of organic matter in soils with different texture. Soil Biol. Biochem. 28:1367-1372.

Frey, S.D., E.T. Elliott, and K. Paustian. 1999. Bacterial and fungal abundance and biomass in conventional and no-tillage agroecosystems along two climatic gradients. Soil Biol. Biochem. 31:573-585.

Frey, S.D., J. Six, and E.T. Elliott. 2003. Reciprocal transfer of carbon and nitrogen by decomposer fungi at the soil-litter interface. Soil Biol. Biochem. 35:1001-1004.

Frey, S.D., E.T. Elliott, K. Paustian, and G.A. Peterson. 2000. Fungal translocation as a mechanism for soil nitrogen inputs to surface residue decomposition in no-tillage agroecosystem. Soil Biol. Biochem. 32:689-698.

Frey, S.D., V.V.S.R. Gupta, E.T. Elliott, and K. Paustian. 2001. Protozoan grazing affects estimates of carbon utilization efficiency of the soil microbial community. Soil Biol. Biochem. 33:1759-1768.

Frey, S.D., M. Knorr, J. Parrent, and R.T. Simpson. 2004. Chronic nitrogen enrichment affects the structure and function of the soil microbial community in a forest ecosystem. For. Ecol. Manage. 196:159-171.

Gorres, J.H., M.C. Savin, D.A. Neher, T.R. Weicht, and J.A. Amador. 1999. Grazing in a porous environment: 1 .The effect of soil pore structure on C and N mineralization. Plant Soil 212:75-83.

Gregorich, E.G., R.P. Voroney, and R.G. Kachnoski. 1991. Turnover of carbon through the microbial biomass in soils with different textures. Soil Biol. Biochem. 23:799-805.

Guggenberger, G., W. Zech, and R.J. Thomas. 1995. Lignin and carbohydrate alteration in particle-size separates of an oxisol under tropical pastures following native savanna. Soil Biol. Biochem. 27:1629-1638.

Guggenberger, G., S.D. Frey, J. Six, K. Paustian, and E.T. Elliott. 1999. Bacterial and fungal cell-wall residues in conventional and notillage agroecosystems. Soil Sci. Soc. Am. J. 63:1188-1198.

Gunapala, N., R.C. Venette, H. Ferris, and K.M. Scow. 1998. Effects of soil management history on the rate of organic matter decomposition. Soil Biol. Biochem. 30:1917-1927.

Gupta, V.V.S.R., and J.J. Germida. 1988. Distribution of microbial biomass and its activity in different soil aggregate size classes as affected by cultivation. Soil Biol. Biochem. 20:777-786. 
Gupta, V.V.S.R., M.M. Roper, J.A. Kirkegaard, and J.F. Angus. 1994. Changes in microbial biomass and organic matter levels during the first year of modified tillage and stubble management practices on a red Earth. Aust. J. Soil Res. 32:1339-1354.

Harley, J.L. 1971. Fungi in ecosystems. J. Animal Ecol. 41:1-16.

Hart, S.C., G.E. Nason, D.D. Myrold, and D.A. Perry. 1994. Dynamics of gross nitrogen transformations in an old-growth forest: The carbon connection. Ecology 75:880-891.

Hassink, J., G. Lebbink, and J.A. VanVeen. 1991. Microbial biomass and activity of a reclaimed-polder soil under a conventional and a reduced-input farming system. Soil Biol. Biochem. 23:507-514.

Haynes, R.J., and R.S. Swift. 1990. Stability of soil aggregates in relation to organic constituents and soil water content. J. Soil Sci 41:73-83.

Haynes, R.J., and G.S. Francis. 1993. Changes in microbial biomass C, soil carbohydrate composition and aggregate stability induced by growth of selected crop and forage species under field conditions. J. Soil Sci. 44:665-667.

Heijnen, C.E., C.H. Hok-A-Hin, and J.A. van Veen. 1991. Protection of Rhizobium by bentonite clay against predation by flagellates in liquid cultures. FEMS Microbiol. Ecol. 85:65-72.

Heijnen, C.E., and J.A. van Veen. 1991. A determination of protective microhabitats for bacteria introduced into soil. FEMS Microbiol. Ecol. 85:73-80.

Hendrix, P.F., R.W. Parmelee, D.A. Crossley, Jr., D.C. Coleman, E.P. Odum, and P.M. Groffman. 1986. Detritus food webs in conventional and no-tillage agroecosystems. Bioscience 36:374-379.

Holland, E.A., and D.C. Coleman. 1987. Litter placement effects on microbial and organic matter dynamics in an agroecosystem. Ecology 68:425-433.

Hu, S., D.C. Coleman, M.H. Beare, and P.F. Hendrix. 1995. Soil carbohydrates in aggrading and degrading agroecosystems: Influences of fungi and aggregates. Agric. Ecosyst. Environ. 54:77-88.

Jackson, L.E., F.J. Calderon, K.L. Steenwerth, K.M. Scow, and D.E. Rolston. 2003. Responses of soil microbial processes and community structure to tillage events and implications for soil quality. Geoderma 114:305-317.

Jocteur-Monrozier, L.J., J.N. Ladd, R.W. Fitzpatrick, R.C. Foster, and M. Raupach. 1991. Components and microbial biomass content of size fractions in soils of contrasting aggregation. Geoderma 49: $37-62$.

Kandeler, E., D. Tscherko, and H. Spiegel. 1999a. Long-term monitoring of microbial biomass, $\mathrm{N}$ mineralisation and enzyme activities of a Chernozem under different tillage management. Biol. Fertil. Soils 28:343-351.

Kandeler, E., M. Stemmer, and E.-M. Klimanek. 1999b. Response of soil microbial biomass, urease and xylanase within particle size fractions to long-term soil management. Soil Biol. Biochem. 31:261-273.

Killham, K. 1994. Soil ecology. Cambridge Univ. Press, Cambridge, UK.

Klein, D.A., T. McLendon, M.W. Paschke, and E.F. Redente. 1996. Nitrogen availability and fungal-bacterial responses in successional semi-arid steppe soils. Arid Soil Res. Rehabil. 10:321-332.

Knicker, H., G. Almendros, F.J. Gonzalez-Vila, H.-D. Ludemann, and F. Martin. $1995 .{ }^{13} \mathrm{C}$ and ${ }^{15} \mathrm{~N}$ NMR analysis of some fungal melanins in comparison with soil organic matter. Org. Geochem. 23:1023-1028.

Kogel-Knabner, I. 2002. The macromolecular organic composition of plant and microbial residues as inputs to soil organic matter. Soil Biol. Biochem. 34:139-162.

Kuikman, P.J., M.M.I. Van Vuuren, and J.A. Van Veen. 1989. Effect of soil moisture regime on predation by protozoa of bacterial biomass and the release of bacterial nitrogen. Agric. Ecosyst. Environ. 27: 271-279.

Kuo, S., U.M. Sainju, and E.J. Jellum. 1997. Winter cover crop effects on soil organic carbon and carbohydrate in soil. Soil Sci. Soc. Am. J. $61: 145-152$.

Ladd, J.N., J.W. Parsons, and M. Amato. 1977a. Distribution of immobilized nitrogen amongst soil fractions of different particle size and density. Soil Biol. Biochem. 9:309-318.

Ladd, J.N., J.W. Parsons, and M. Amato. 1977b. Studies of nitrogen immobilization and mineralization in calcareous soils. II. Mineralization of immobilized nitrogen from soil fractions of different particle size and density. Soil Biol. Biochem. 9:319-325.

Ladd, J.N., M. Amato, and J.W. Parsons. 1977c. Studies of nitrogen immobilization and mineralization in calcareous soils. III. Concen- tration and distribution of nitrogen derived from the soil biomass p. 301-310. Soil organic matter studies. Vol. 1. Proceedings IAEA/ FAO/SSF Symposium, Braunschweig, 1976. International Atomic Energy Agency, Vienna.

Ladd, J.N., L. Jocteur-Monrozier, and M. Amato. 1992. Carbon turnover and nitrogen transformations in an alfisol and vertiso amended with $\left[\mathrm{U}_{-14}{ }^{14} \mathrm{C}\right]$ glucose and $\left[{ }^{15} \mathrm{~N}\right]$ ammonium sulfate. Soil Biol. Biochem. 24:359-371.

Ladd, J.N., M. Van Gestel, L.J. Monrozier, and M. Amato. 1996. Distribution of organic ${ }^{14} \mathrm{C}$ and ${ }^{15} \mathrm{~N}$ in particle-size fractions of soils incubated with ${ }^{14} \mathrm{C},{ }^{15} \mathrm{~N}$-labelled glucose $/ \mathrm{NH}_{4}$ and legume and wheat straw residues. Soil Biol. Biochem. 28:893-905.

Lekkerkerk, L., H. Lundkvist, and G.I. Ågren. 1990. Decomposition of heterogeneous substrates; an experimental investigation of a hypothesis on substrate and microbial properties. Soil Biol. Biochem. 22:161-168.

Lindeberg, G., and M. Lindeberg. 1977. Pectinolytic ability of some mycorrhizal and saprophytic hymenomycetes. Arch. Microbiol. 115:9-12.

Linhares, L.F., and J.P. Martin. 1978. Decomposition in soil of the humic acid-type polymers (melanins) of Eurotium echinulatum, Aspergillus glaucus Sp. and other fungi. Soil Sci. Soc. Am. J. 42: 738-743.

Lundberg, P., A. Ekblad, and M. Nilsson. 2001. ${ }^{13} \mathrm{C}$ NMR spectroscopy studies of forest soil microbial activity: Glucose uptake and fatty acid biosynthesis. Soil Biol. Biochem. 33:621-632.

Lundquist, E.J., L.E. Jackson, K.M. Scow, and C. Hsu. 1999. Changes in microbial biomass and community composition, and soil carbon and nitrogen pools after incorporation of rye into three California agricultural soils. Soil Biol. Biochem. 31:221-236.

Lupwayi, N.Z., W.A. Rice, and G.W. Clayton. 1999. Soil microbial biomass and carbon dioxide flux under wheat as influenced by tillage and crop rotation. Can. J. Soil Sci. 79:273-280.

Martin, J.P., and K. Haider. 1979. Biodegradation of ${ }^{14} \mathrm{C}$-labeled model and cornstalk lignins, phenols, model phenolase humic polymers, and fungal melanins as influenced by a readily available carbon source and soil. Appl. Environ. Microbiol. 38:283-289.

Martin, J.P., and K. Haider. 1986. Influence of mineral colloids on turnover rates of soil organic carbon. p. 283-304. In P.M. Huang and M. Shnitzer (ed.) Interactions of soil minerals with natural organics and microbes. SSSA Special Pub. No. 17. SSSA, Madison, WI.

Martin, J.P., Z. Filip, and K. Haider. 1976. Effect of montmorillonite and humate on growth and metabolic activity of some actinomycetes. Soil Biol. Biochem. 8:409-413.

McGill, W.B., J.A. Shields, and E.A. Paul. 1975. Relation between carbon and nitrogen turnover in soil organic fractions of microbial origin. Soil Biol. Biochem. 7:57-63.

McGonigle, T., M.H. Miller, and D. Young. 1999. Mycorrhizae, crop growth, and crop phosphorus nutrition in maize-soybean rotation given various tillage treatments. Plant Soil 210:33-42.

Miller, M., and R.P. Dick. 1995. Dynamics of soil C and microbial biomass in whole soil and aggregates in two cropping systems. Appl. Soil Ecol. 2:253-261.

Miller, R.M., and D.J. Lodge. 1997. Fungal responses to disturbance: Agriculture and forestry. p. 65-84. In Wicklow and Soderstrom (ed.) The mycota IV: Environmental and microbial relationships. Springer-Verlag, Berlin, Germany.

Mummey, D.L., and P.D. Stahl. 2004. Analysis of soil whole- and innermicroaggregate bacterial communities. Microb. Ecol. 48:41-50.

Mummey, D.L., W.E. Holben, J. Six, and P.D. Stahl. 2005. Spatial stratification of soil microbial populations in diverse soils: Rubrobacteria and Gemmatimonads are abundant in water-stable microaggregate interiors while Acidobacteria are primarily associated with macroaggregates. Microb. Ecol. (in press).

Nakas, J.P., and D.A. Klein. 1979. Decomposition of microbial cell components in a semi-arid grassland soil. Appl. Environ. Microbiol. $38: 454-460$

Neely, C.L., M.H. Beare, W.L. Hargrove, and D.C. Coleman. 1991 Relationships between fungal and bacterial substrate-induced respiration, biomass, and plant residue decomposition. Soil Biol. Biochem. 23:947-954.

Neher, D.A., T.R. Weicht, M.C. Savin, J.H. Gorres, and J.A. Amador 1999. Grazing in a porous environment. 2. Nematode community structure. Plant Soil 215:85-99. 
Oades, J.M. 1967. Carbohydrates in some Australian soils. Aust. J. Soil Res. 5:103-115.

Oades, J.M. 1984. Soil organic matter and structural stability: Mechanisms and implications for management. Plant Soil 76:319-337.

Oades, J.M. 1990. Associations of colloids in soil aggregates. p. 463483. In M.F. De Boodt et al. (ed.) Soil colloids and their association in aggregates. Plenum Press, New York

Ogle, S.M., F.J. Breidt, M. Eve, and K. Paustian. 2003. Uncertainty in estimating land use and management impacts on soil organic carbon storage for US agricultural lands between 1982-1997. Global Change Biol. 9:1521-1542.

O'Halloran, I.P., M.H. Miller, and G. Arnold. 1986. Absorption of P by corn (Zea mays L.) as influenced by soil disturbance. Can. J. Soil Sci. 66:287-302.

Ohtonen, R., H. Fritze, T. Pennanen, A. Jumpponen, and J. Trappe. 1999. Ecosystem properties and microbial community changes in primary succession on a glacier forefront. Oecologia 119:239-246.

Parsons, L.L., and M.S. Smith. 1989. Microbial utilization of carbon14-glucose in aerobic vs. anaerobic denitrifying soils. Soil Sci. Soc. Am. J. 53:1082-1085.

Parton, W.J., D.S. Schimel, C.V. Cole, and D.S. Ojima. 1987. Analysis of factors controlling soil organic matter levels in Great Plains grasslands. Soil Sci. Soc. Am. J. 51:1173-1179.

Paustian, K., H.P. Collins, and E.A. Paul. 1997. Management controls on soil carbon. p. 15-49. In E. A. Paul et al. (ed.) Soil organic matter in temperate agroecosystems. CRC Press, Boca Raton, FL.

Paustian, K., J. Six, E.T. Elliott, and H.W. Hunt. 2000. Management options for reducing $\mathrm{CO}_{2}$ emissions from agricultural soils. Biogeochemistry 48:147-163.

Payne, W.J. 1970. Energy yields and growth of heterotrophs. Annu. Rev. Microbiol. 24:17-52.

Payne, W.J., and W.J. Wiebe. 1978. Growth yield and efficiency in chemosynthetic microorganisms. Annu. Rev. Microbiol. 32:155-183.

Petersen, S.O., K. Debosz, P. Schjønning, B.T. Christensen, and S. Elmholt. 1997. Phospholipid fatty acid profiles and C availability in wet-stable macro-aggregates from conventionally and organically farmed soils. Geoderma 78:181-196.

Peterson, G.A., A.D. Halvorson, J.L. Havlin, O.R. Jones, D.J. Lyon, and D.L. Tanaka. 1998. Reduced tillage and increasing cropping intensity in the Great Plains conserves soil C. Soil Tillage Res. 47: 207-218.

Puget, P., D.A. Angers, and C. Chenu. 1999. Nature of carbohydrates associated with water-stable aggregates of two cultivated soils. Soil Biol. Biochem. 31:55-63.

Qin, R., P. Stamp, and W. Richner. 2005. Impact of tillage and banded starter fertilizer on maize root growth in the top 25 centimeters of the soil. Agron. J. 97:674-683.

Rillig, M.C., S.F. Wright, M.F. Allen, and C.B. Field. 1999. Soil biota responses to long term atmospheric $\mathrm{CO}_{2}$ enrichment in two California annual grasslands. Oecologia 119:572-577.

Rivkin, R.B., and L. Legendre. 2001. Biogenic carbon cycling in the upper ocean: Effects of microbial respiration. Science (Washington, DC) 291:2398-2400.

Roberson, E.B., S. Sarig, and M.K. Firestone. 1991. Cover crop management of polysaccharide-mediated aggregation in an orchard soil. Soil Sci. Soc. Am. J. 55:734-739.

Roberson, E.B., S. Sarig, C. Shennan, and M.K. Firestone. 1995. Nutritional management of microbial polysaccharide production and aggregation in an agricultural soil. Soil Sci. Soc. Am. J. 59: 1587-1594.

Rodionov, A., W. Amelung, I. Urusevskaja, and W. Zech. 2001. Origin of the enriched labile fraction (ELF) in Russian Chernozems with different site history. Geoderma 102:299-315.

Rutherford, P.M., and N.G. Juma. 1992. Influence of soil texture on protozoa-induced mineralization of bacterial carbon and nitrogen. Can. J. Soil Sci. 72:183-200.

Sakamoto, K., and Y. Oba. 1994. Effect of fungal to bacterial biomass ratio on the relationship between $\mathrm{CO}_{2}$ evolution and total soil microbial biomass. Biol. Fertil. Soils 17:39-44.

Savin, M.C., J.H. Gorres, D.A. Neher, and J.A. Amador. 2001. Uncoupling of carbon and nitrogen mineralization: Role of microbivorous nematodes. Soil Biol. Biochem. 33:1463-1472.

Schimel, D.S. 1988. Calculation of microbial growth efficiency from ${ }^{15} \mathrm{~N}$ immobilization. Biogeochemistry 6:239-243.
Schlesinger, W.H. 1997. Biogeochemistry: An analysis of global change. 2nd ed. Academic Press Inc., San Diego, CA.

Schnürer, J., M. Clarholm, and T. Rosswall. 1985. Microbial biomass and activity in an agricultural soil with different organic matter contents. Soil Biol. Biochem. 17:611-618.

Schrickx, J.M., A.S. Krave, J.C. Verdoes, C.A.M.J.J. van den Hondel, A.H. Stouthamer, and H.W. van Verseveld. 1993. Growth and product formation in chemostat and recycling cultures by Aspergillus niger $\mathrm{N} 402$ and a glucoamylase overproducing transformant, provided with multiple copies of the glaA gene. J. Gen. Microbiol. 139:2801-2810.

Schutter, M.E., and R.P. Dick. 2002. Microbial community profiles and activities among aggregates of winter fallow and cover-cropped soil. Soil Sci. Soc. Am. J. 66:142-153.

Scow, K.M. 1997. Soil microbial communities and carbon flow in agroecosystems. p. 367-413. In L.E. Jackson (ed.) Ecology in agriculture. Academic Press, San Diego, CA.

Seto, M., and K. Misawa. 1982. Growth rate, biomass production and carbon balance of Pseudomonas aeruginosa in glucose-limited medium at temperature and osmotic pressure extremes. J. Ecol. (Japan) 32:365-371.

Seto, M., and M. Noda. 1982. Growth rate, biomass production and carbon balance of Pseudomonas aeruginosa at $\mathrm{pH}$ extremes in a carbon-limited medium. J. Limnol. (Japan) 43:263-271.

Shen, J., and R. Bartha. 1996. Metabolic efficiency and turnover of soil microbial communities in biodegradation tests. Appl. Environ. Microbiol. 62:2411-2415.

Shields, J.A., E.A. Paul, and W.E. Lowe. 1973. Turnover of microbial tissue in soil under field conditions. Soil Biol. Biochem. 5:753-764.

Simpson, R.T., S.D. Frey, J. Six, and R.K. Thiet. 2004. Preferential accumulation of microbial carbon in aggregate structures of notillage soils. Soil Sci. Soc. Am. J. 68:1249-1255.

Six, J., E.T. Elliott, and K. Paustian. 1999. Aggregate and soil organic matter dynamics under conventional and no-tillage systems. Soil Sci. Soc. Am. J. 63:1350-1358.

Six, J., E.T. Elliott, and K. Paustian. 2000a. Soil macroaggregate turnover and microaggregate formation: A mechanism for C sequestration under no-tillage agriculture. Soil Biol. Biochem. 32:2099-2103.

Six, J., E.T. Elliott, K. Paustian, and J.W. Doran. 1998. Aggregation and soil organic matter accumulation in cultivated and native grassland soils. Soil Sci. Soc. Am. J. 62:1367-1377.

Six, J., K. Paustian, E.T. Elliott, and C. Combrink. 2000b. Soil structure and organic matter: I. Distribution of aggregate-size classes and aggregate-associated carbon. Soil Sci. Soc. Am. J. 64:681-689.

Six, J., R. Merckx, K. Kimpe, K. Paustian, and E.T. Elliott. 2000c. A re-evaluation of the enriched labile soil organic matter fraction. Eur. J. Soil Sci. 51:283-293.

Six, J., G. Guggenberger, K. Paustian, L. Haumaier, E.T. Elliott, and W. Zech. 2001. Sources and composition of soil organic matter fractions between and within soil aggregates. Eur. J. Soil Sci. 52:607-618.

Six, J., C. Feller, K. Denef, S.M. Ogle, M.J.C. Sa, and A. Albrecht. 2002. Soil organic matter, biota and aggregation in temperate and tropical soils- effects of no-tillage. Agron. Agric. Environ. 22:755-775.

Søndergaard, M., P.J.B. Williams, G. Cauwet, B. Riemann, C. Robinson, S. Terzic, E.M.S. Woodward, and J. Worm. 2000. Net accumulation and flux of dissolved organic carbon and dissolved organic nitrogen in marine plankton communities. Limnol. Oceanogr. 45:1097-1111.

Sorensen, L.H. 1974. Rate of decomposition of organic matter in soil as influenced by repeated air drying-rewetting and repeated additions of organic material. Soil Biol. Biochem. 6:287-292.

Sorensen, L.H. 1983a. Size and persistence of the microbial biomass formed during the humification of glucose, cellulose, and straw in soils containing different amounts of clay. Plant Soil 75:121-130.

Sorensen, L.H. 1983b. The influence of stress treatments on the microbial biomass and the rate of decomposition of humified matter in soils containing different amounts of clay. Plant Soil 75: $107-119$.

Sorensen, P., J.N. Ladd, and M. Amato. 1996. Microbial assimilation of ${ }^{14} \mathrm{C}$ of ground and unground plant materials decomposing in a loamy sand and a clay soil. Soil Biol. Biochem. 28:1425-1434.

Stotzky, G. 1966. Influence of clay minerals on microorganizms. III. Effect of particle size, cation exchange capacity, and surface area on bacteria. Can. J. Microbiol. 12:1235-1246. 
Stotzky, G., and L.T. Rem. 1966. Influence of clay minerals on microorganizms. I. Montmorillonite and kaolinite on bacteria. Can. J. Microbiol. 12:547-563.

Suberkropp, K. 1991. Relationships between growth and sporulation of aquatic hyphomycetes on decomposing leaf litter. Mycol. Res. 95:843-850.

Swanston, C., P.S. Homann, B.A. Caldwell, D.D. Myrold, L. Ganio, and P. Sollins. 2004. Long-term effects of elevated nitrogen on forest soil organic matter stability. Biogeochemistry 70: 229-252.

Sylvia, D.M., J.J. Fuhrmann, P.G. Hartel, and D.A. Zuberer. 2005. Principles and applications of soil microbiology. 2nd ed. Pearson Education Inc., Upper Saddle River, NJ.

Thiet, R.K., S.D. Frey, and J. Six. 2005. Do growth yield efficiencies differ between soil microbial communities differing in fungal:bacterial ratios? Reality check and methodological issues. Soil Biol. Biochem. doi:10.1016/j.soilbio.2005.07.010.

Thompson, J.P. 1987. Decline of vesicular-arbuscular mycorrhizae in long fallow disorder of field crops and its expression in phosphorous deficiency of sunflower. Aust. J. Agric. Res. 38:847-867.

Tisdall, J.M. 1994. Possible role of soil microorganisms in aggregation in soils. Plant Soil 159:115-121.

Tisdall, J.M., and J.M. Oades. 1982. Organic matter and water-stable aggregates in soils. J. Soil Sci. 62:141-163.

Van Gestel, M., R. Merckx, and K. Vlassak. 1996. Spatial distribution of microbial biomass in microaggregates of a silty-loam soil and the relation with the resistance of microorganisms to soil drying. Soil Biol. Biochem. 28:503-510.

van Veen, A.J., J.N. Ladd, and M. Amato. 1985. Turnover of carbon and nitrogen through the microbial biomass in a sandy loam and a clay soil incubated with ${ }^{14} \mathrm{C}(\mathrm{U})$ glucose and ${ }^{15} \mathrm{~N}\left(\mathrm{NH}_{4}\right)_{2} \mathrm{SO}_{4}$ under different moisture regimes. Soil Biol. Biochem. 17:747-756.

Vargas, R., and T. Hattori. 1986. Protozoan predation of bacterial cells in soil aggregates. FEMS Microbiol. Ecol. 38:233-242.

Vivekanandan, M., and P.E. Fixen. 1991. Cropping systems effects on mycorrhizal colonization, early growth, and phosphorus uptake of corn. Soil Sci. Soc. Am. J. 55:136-140.

Waksman, S.A. 1929. Chemical and microbiological principles underlying the decomposition of green manures in the soil. J. Am. Soc. Agron. 21:1-18.
Wardle, D.A. 1995. Impacts of disturbance on detritus food webs in agro-ecosystems of contrasting tillage and weed management practices. Adv. Ecol. Res. 26:107-185.

Wardle, D.A., and A. Ghani. 1995. A critique of the microbial metabolic quotient $\left(\mathrm{qCO}_{2}\right)$ as a bioindicator of disturbance and ecosystem development. Soil Biol. Biochem. 12:1601-1610.

Wardle, D.A., G.W. Yeates, R.N. Watson, and K.S. Nicholson. 1995 The detritus food-web and diversity of soil fauna as indicators of disturbance regimes in agro-ecosystems. Oikos 73:155-166.

West, T.O., and W.M. Post. 2002. Soil organic carbon sequestration rates by tillage and crop rotation: A global data analysis. Soil Sci. Soc. Am. J. 66:1930-1946.

Wright, S.F., and A. Upadhyaya. 1996. Extraction of an abundant and unusual protein from soil and comparison with hyphal protein of arbuscular mycorrhizal fungi. Soil Sci. 161:575-586.

Wright, S.F., and R.L. Anderson. 2000. Aggregate stability and glomalin in alternative crop rotations for the central Great Plains. Biol. Fertil. Soils 31:249-253.

Wright, S.F., M. Frank-Snyder, J.B. Morton, and A. Upadhyaya. 1996 Time-course study and partial characterization of protein on a hyphae of arbuscular mycorrhizal fungi during active colonization of roots. Plant Soil 181:193-203.

Yeates, G.W., R.D. Bardgett, R. Cook, P.J. Hobbs, P.J. Bowling, and J.F. Potter. 1997. Faunal and microbial diversity in three Welsh grassland soils under conventional and organic management regimes. J. Appl. Ecol. 34:453-471.

Zak, D.R., D.B. Ringelberg, K.S. Pregitzer, D.L. Randlett, D.C. White, and P.S. Curtis. 1996. Soil microbial communities beneath Populus grandidentata grown under elevated atmospheric $\mathrm{CO}_{2}$. Ecol. Appl. 6:257-262.

Zelles, L. 1988. The simultaneous determination of muramic acid and glucosamine in soil by high-performance liquid chromatography with precolumn fluorescence derivatization. Biol. Fertil. Soils 6 : $125-130$.

Zhang, X., and W. Amelung. 1996. Gas chromatographic determination of muramic acid, glucosamine, mannosamine, and galactosamine in soils. Soil Biol. Biochem. 28:1201-1206.

Zhang, X., W. Amelung, Y. Yuan, and W. Zech. 1998. Amino sugar signature of particle-size fractions in soils of the native prairie as affected by climate. Soil Sci. 163:220-229. 